\title{
WHAT HAPPENED TO THE CLASS OF 2010? EMPIRICAL EVIDENCE OF STRUCTURAL CHANGE IN THE LEGAL PROFESSION
}

\author{
Deborah Jones Merritt*
}

2015 MiCH. ST. L. REV. 1043

TABLE OF CONTENTS

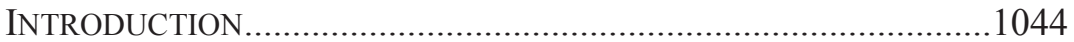

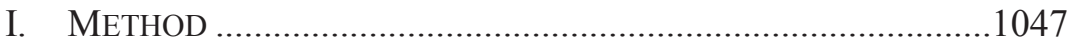

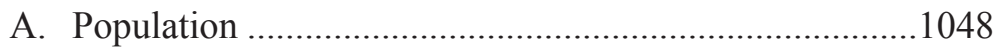

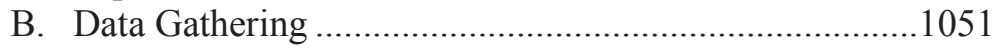

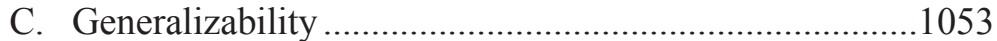

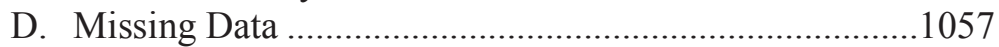

E. Study Limits ........................................................................1060

II. RESUlts: CAREER PROGRESSION FOR THE ClASS OF 2010 ...1063

A. Law Firm Employment ...............................................1069

B. Government and Public Interest ....................................1075

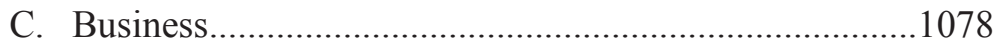

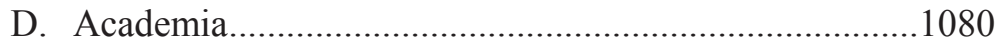

E. Solo Practitioners ............................................................1081

F. Jobs Requiring Bar Admission...................................1082

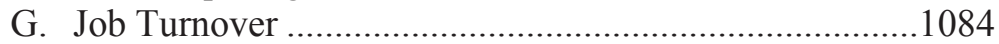

III. GENDER, PRESTIGE, AND GEOGRAPHIC MOBILITY .................1087

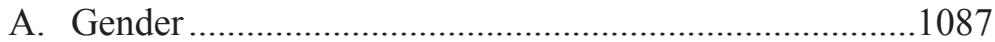

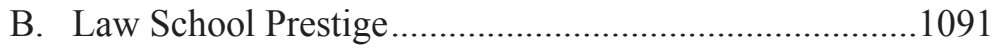

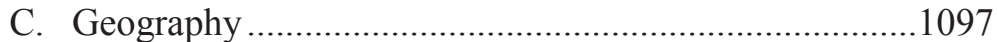

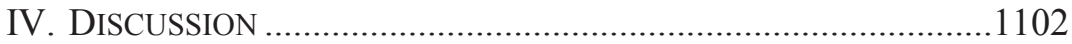

A. Disruptive Forces in the Legal Market..........................1104

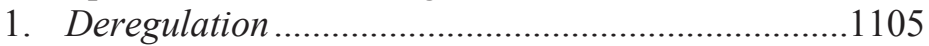

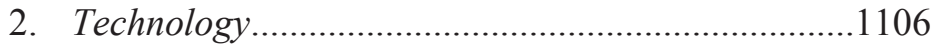

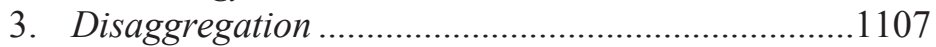

4. Compliance and Other Law-Related Work..............1108

* John Deaver Drinko/Baker \& Hostetler Chair in Law, Moritz College of Law, The Ohio State University. I am grateful for the help of my excellent research assistant, Molly Werhan, as well as for insightful comments by Roy Worthy Campbell, Paul Campos, Herbert Kritzer, Kyle McEntee, Alan Michaels, Amy Otto, Michael Simkovic, and Brian Tamanaha. Those colleagues sometimes disagree with one another, as well as with me, which made their comments even more helpful. 
5. Global Competition ....................................................1109

6. Oversupply of Lawyers ............................................ 1109

B. Entry-Level Lawyers and the Economics of Legal

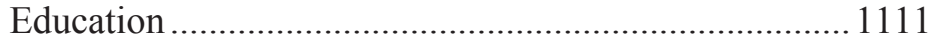

1. Flat Demand for New Lawyers ............................... 1112

2. Modest-Paying Legal Jobs ...................................... 1115

3. Law School Enrollment ............................................1116

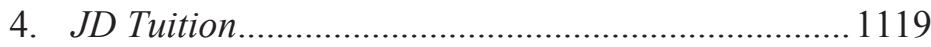

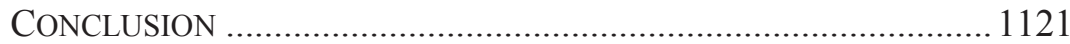

\section{INTRODUCTION}

The law school Class of 2010 faced a bleak employment market. Nine months after graduation, only $87.6 \%$ of the class reported a job of any type. ${ }^{1}$ More than a tenth of the employed graduates were working part-time, ${ }^{2}$ and more than a fifth held jobs that did not require a law license. ${ }^{3}$ As the National Association for Law Placement (NALP) declared when releasing these figures, the job market for 2010 graduates was afflicted by "many underlying structural weaknesses" and represented "the interruption of employment patterns for new law school graduates that ha[d] been undisturbed for decades."

1. NalP, Class of 2010 Graduates Faced Worst Job Market Since Mid-1990s: Longstanding EMPloyment PATterns InTERrupted 1 (2011), http://www.nalp.org/uploads/Classof2010SelectedFindings.pdf.

2. NALP, Class OF 2010 NATIONAL Summary Report (2011), http://www.nalp.org/uploads/NationalSummaryChartforSchools2010.pdf (reporting that $10.9 \%$ of employed graduates were working part-time).

3. See id. (reporting that 7,453 graduates were working in jobs that did not require bar admission, out of 35,620 employed graduates for whom job type was known). NALP uses the phrase "bar admission required" to designate jobs that require a law license. Throughout this Article, I use the phrases "bar admission required," "job requiring a law license," and "lawyering job" interchangeably to designate that category of jobs. Like NALP and other sources, I include judicial clerkships in the category of jobs requiring bar admission. See NALP, NALP Graduate Employment Survey for the Class of 2014: Frequently Asked QUESTIONS (2014), http://www.nalp.org/uploads/ERSS/2014gradsurveywFAQs june2014.pdf.

4. Press Release, NALP, Class of 2010 Graduates Faced Worst Job Market Since Mid-1990s: Longstanding Employment Patterns Interrupted (June 1, 2011), http://www.nalp.org/2010selectedfindingsrelease. The National Association for Law Placement is an organization of legal career professionals. For a detailed analysis of the data produced by NALP, see generally Bernard A. Burk, What's New About the New Normal: The Evolving Market for New Lawyers in the 21st Century, 41 FLA. ST. U. L. REV. 541 (2014). 
Some scholars predicted that the setbacks would prove temporary and that the new graduates would reap better jobs as the economy recovered or they honed their practice skills. ${ }^{5}$ Others were more pessimistic, warning that the negative employment patterns reflected structural shifts in the legal employment market. ${ }^{6}$ As the members of the Class of 2010 reach the fifth anniversary of their law school graduation, it is possible to begin examining actual career outcomes for the class.

This Article offers the first in-depth look at those employment outcomes. ${ }^{7}$ Using court records and other publicly available sources, I compiled comprehensive data on December 2014 jobs for lawyers who passed the 2010 bar exam in a large, representative state. In addition to analyzing these positions, I compare the population's current employment pattern to the ones that NALP described for the national Class of 2010 nine months after graduation. ${ }^{8}$ I also contrast outcomes for the research population with those provided by the Class of 2000 as part of the After the JD (AJD) study. The latter project is a highly regarded longitudinal survey conducted by the

5. See, e.g., Michael Simkovic \& Frank McIntyre, The Economic Value of a Law Degree, 43 J. Legal STUD. 249, 271-76 (2014); Steven Davidoff Solomon, Debating, Yet Again, the Worth of Law School, N.Y. Times (July 18, 2013, 11:44 AM), http://dealbook.nytimes.com/2013/07/18/debating-yet-again-the-worth-of-lawschool/; Benjamin Barros, Reconsidering the Conventional Wisdom on the Legal Job Market (Widener Law Sch. Legal Studies Research Paper Series, No. 13-60, 2013), http://papers.ssrn.com/sol3/papers.cfm?abstract_id=2258806.

6. See, e.g., Burk, supra note 4; Paul Campos, The Crisis of the American Law School, 46 U. Mich. J.L. Reform 177, 179 (2012); William D. Henderson, Three Generations of U.S. Lawyers: Generalists, Specialists, Project Managers, 70 MD. L. REV. 373, 374 (2011); Deborah Jones Merritt, The Job Gap, the Money Gap, and the Responsibility of Legal Educators, 41 WASH. U. J.L. \& POL'Y 1, 2 (2013); Milton C. Regan, Jr. \& Palmer T. Heenan, Supply Chains and Porous Boundaries: The Disaggregation of Legal Services, 78 FordHAM L. REV. 2137, 2138 (2010); Larry E. Ribstein, The Death of Big Law, 2010 Wis. L. REV. 749, 752.

7. Benjamin Barros conducted an earlier study on career outcomes for 2010 and 2011 graduates of his own law school (Widener Law's Harrisburg campus) and published those results as both a working paper and series of blog posts. See Barros, supra note 5. By limiting his inquiry to a single school, however, Barros can draw only limited conclusions about outcomes for the class as a whole. See also infra notes 21-24 and accompanying text (discussing limits of studies focused on single schools).

8. NALP collects employment data from law schools each year and publishes aggregate information in an annual report titled Jobs \& JDs. See infra note 22 and accompanying text for more detail on NALP's annual data reports. 
American Bar Foundation and the NALP Foundation for Law Career Research and Education. ${ }^{9}$

My analyses suggest that job outcomes for the Class of 2010 have improved only marginally since their first year after graduation. Although all members of the research population hold a law license, only three-quarters of them use that license in the workplace..$^{10}$ Just half the population engages in private practice, and one-fifth of those private practitioners work in solo offices. ${ }^{11}$ These outcomes contrast markedly with prior research on the profession, including data collected by NALP and $A J D$ for early career development of the Class of 2000.

My data also yielded key insights on three characteristics frequently associated with workplace achievement. First, significant gender differences emerged in the research population. Although these gaps resemble those identified among earlier groups of graduates, the disparities appear larger. ${ }^{12}$ Second, job outcomes for the research population-like those in other studies of the legal population-are stratified by the prestige of the schools they attended..$^{13}$ Finally, geography played a marked role in shaping the population, and that factor interacted with both gender and school prestige. ${ }^{14}$

9. Those organizations launched $A J D$ in the late 1990 s "to track the careers of a nationally representative cohort of lawyers admitted to the bar in the year 2000." Robert L. Nelson \& Gabriele Plickert, Introduction to AFTER THE JD III: Third Results from a National Study of Legal Careers 13, 14 (Am. Bar Found. \& NALP Found. for Law Career Research \& Educ. eds., 2014) [hereinafter AJD III].

10. See infra Part II.

11. Solo practitioners technically constitute "law firms," and many sources count them within that larger category. I distinguish solos from other law firms throughout most of my discussion, because solo practice differs substantially from other firm settings for new lawyers. When discussing both solos and attorneys practicing at larger firms, I use the phrase "private practice."

My data suggest that a larger percentage of the class was employed in December 2014 than in February 2011. See infra Part II. Although this is a welcome shift, it is not particularly noteworthy for young adults holding advanced educational degrees. In noting the "marginal" improvement in the class's employment pattern, I focus on the nature of the jobs held by the class.

12. See infra Section III.A.

13. See infra Section III.B.

14. See infra Section III.C. Unfortunately, I could not examine associations between job outcomes and race or ethnicity because my research sources did not identify those characteristics. See infra note 77 for several excellent sources discussing the relationship of race or ethnicity to legal careers. 
The findings of this study, combined with industry trends identified by both practitioners and scholars, support the existence of structural shifts in the legal employment market. These changes raise questions about career prospects for law graduates, as well as about the cost and structure of legal education. I examine those issues in Part IV of the Article, offering two predictions about the job market for junior lawyers and two forecasts about that market's impact on legal education. To lay the foundation for that discussion, Part I outlines my research method, Part II presents key results, and Part III looks more closely at associations of employment outcomes with gender, geographic mobility, and law school prestige.

\section{METHOD}

Many studies of the legal profession rely on surveys. That method allows researchers to gather a wide range of information, including personal opinions and other data that are not readily available from public sources. ${ }^{15}$ Properly designed surveys, however, can be expensive and time consuming to administer. ${ }^{16}$ More troubling, response rates are often low; this raises serious concerns about differences between respondents and non-respondents. ${ }^{17}$

For some types of data, the Internet now offers an attractive alternative to survey research. ${ }^{18}$ Lawyers' current jobs appear on

15. The $A J D$ surveys, for example, were able to collect information about respondents' income, job satisfaction, and future plans. See Ronit Dinovitzer \& David Wilkins, The Income of Lawyers-Trends Over Time, in AJD III, supra note 9, at 43, 44-47; Bryant Garth \& Ronit Dinovitzer, Satisfaction, in AJD III, supra note 9, at 49, 50-56; Rebecca Sandefur \& Robert L. Nelson, Mobility and Turnover, in AJD III, supra note 9, at 57, 60-61.

16. See Pew Research Ctr., Assessing the Representativeness of Public OpInION SuRveys 1 (2012), http://www.people-press.org/files/legacypdf/Assessing\%20the\%20Representativeness \%20of\%20Public\%20Opinion $\%$

20Surveys.pdf (noting the "greater effort and expense" that researchers must invest to achieve satisfactory response rates in contemporary surveys).

17. See David S. Moore \& William I. Notz, Statistics: Concepts \& Controversies 53-75 (6th ed. 2006); PeW Research Ctr., supra note 16, at 2. Even the carefully constructed $A J D$ study, for example, achieved response rates of about 50\%. Nelson \& Plickert, supra note 9, at 15. Respondents differed significantly from non-respondents on several key dimensions, including gender, race, geographic region, and law school prestige. Gabriele Plickert, Appendix $B$, in AJD III, supra note 9, at 99-102.

18. See generally Samuel D. Gosling \& Winter Mason, Internet Research in Psychology, 66 AnN. REV. PSYCHOL. 877 (2015); Robert Stebbins, The Internet as a Scientific Tool for Studying Leisure Activities: Exploratory Internet Data Collection, 29 LeISURE STUD. 469 (2010). 
several publicly available sites, including official bar records, commercial directories, employer websites, and professional networking sites like LinkedIn. ${ }^{19}$ At law schools, career service professionals routinely use these sites to generate some of the employment data they collect for each graduating class. ${ }^{20}$ I used the same publicly available information to identify the research population and gather data about population members. In the sections that follow, I briefly describe the population, data gathering method, generalizability, treatment of missing population members, and limitations of this research.

\section{A. Population}

Much research on the legal profession tracks job outcomes for graduates of a particular law school. Every year, for example, schools measure the employment status of their own graduates about nine months after graduation. ${ }^{21}$ Schools submit this information to both NALP and the American Bar Association (ABA), which publish the information in different formats. ${ }^{22}$ Schools also publish

19. LinkedIn is an online professional network with more than 300 million participants worldwide. Press Release, LinkedIn, LinkedIn Announces Fourth Quarter and Full Year 2014 Results (Feb. 5, 2015), https://press.linkedin.com/siteresources/news-releases/2015/linkedin-announces-fourth-quarter-and-full-year2014-results. Participants post current jobs, employment histories, and other careerrelated information on the site. Access to this information depends in part on whether a user purchases one of LinkedIn's premium subscriptions. In that sense, LinkedIn is similar to professional directories sold by other publishers.

20. NALP, NALP Best Practices Guide for Managing Law School EMPLOYMENT OUTCOMES 3, 4 (2012), http://www.nalp.org/uploads/lseotf_guide final.pdf (noting the utility of Internet sources to collect employment data for graduates).

21. See Jeff Sistrunk, ABA Pushes Back Law School Job Data Reporting Timeline, LAw360 (Aug. 13, 2013, 9:11 PM), http:/www.law360.com/articles/ 464762/aba-pushes-back-law-school-job-data-reporting-timeline. Until 2013, schools consistently measured employment status nine months after graduation. $I d$. Starting with the Class of 2014, the reporting date shifted to ten months after graduation. Id. All of the entry-level data discussed in this Article, however, were gathered at the nine-month mark. I refer to these job outcomes as both "entry-level" jobs and "nine-month" ones.

22. NALP publishes some data on its website, see Recent Graduates, NALP, http://www.nalp.org/recentgraduates (last visited Sept. 21, 2015), with more detailed information in its annual report, Jobs \& JDs. See infra notes 43 and 88. The ABA produces annual summary employment charts for each law school, as well as for the graduating class as a whole. In addition, the ABA publishes a spreadsheet with detailed information about employment outcomes at each school. These ABA resources are available at a dedicated website. Employment Summary Report, ABA 
employment data on their websites, as required by an $\mathrm{ABA}$ accreditation standard. ${ }^{23}$ Scholars from several schools, finally, have produced helpful analyses of data gathered from their own graduates. ${ }^{24}$

This school-specific information is useful, but it is difficult to generalize results from one school to another. As graduates move into the workplace, it also becomes harder to follow all members of a particular law school class. For these and other reasons, much research on the legal profession examines a population of bar members rather than of law school graduates..$^{25}$ In 1975, for example, Heinz and Laumann surveyed a random sample of licensed lawyers working within the Chicago city limits. ${ }^{26}$ Twenty years later, Heinz, Laumann, and two collaborators used the same sampling frame to repeat the research. ${ }^{27}$

The most recent scholarly examination of the legal profession, $A J D$, also defined its population based on bar admission. To create a longitudinal study of career outcomes among new lawyers, the $A J D$

Section of Legal Educ. \& Admissions to THE BAR, http://employmentsummary. abaquestionnaire.org (last visited Sept. 21, 2015). Many schools also submit their data to Law School Transparency (LST), an organization that has been instrumental in developing better information about law school outcomes. LST publishes information from schools, as well as data gathered from other sources, in a series of user friendly "score reports." See LST Score Reports, LAW SCH. TRANSPARENCY, http://www.lstscorereports.com (last visited Sept. 21, 2015).

23. ABA SECtion of Legal Educ. \& Admissions to the Bar, ABA Standards AND Rules of Procedure for ApProval of LAW SchOOls 2014-2015 129 (2014), http://www.americanbar.org/content/dam/aba/publications/misc/legal_ education/Standards/2014_2015_aba_standards_and_rules_of_procedure_for_appro val_of_law_schools_bookmarked.authcheckdam.pdf.

24. See, e.g., Barros, supra note 5 (Widener-Harrisburg); Richard O. Lempert, David L. Chambers \& Terry K. Adams, Michigan's Minority Graduates in Practice: The River Runs Through Law School, 25 LAW \& Soc. INQUIRY 395 (2000); Jeffrey Evans Stake, Kenneth G. Dau-Schmidt \& Kaushik Mukhopadhaya, Income and Career Satisfaction in the Legal Profession: Survey Data from Indiana Law School Graduates, 4 J. Empirical Legal Stud. 939 (2007); David B. Wilkins, Bryon Fong \& Ronit DinOvitzer, The Women and MEN of HaRvard LaW School: Preliminary Results from the HLS Career Study (2015), https://clp.law.harvard.edu/assets/HLS-Career-Study-FINAL.pdf.

25. Some national surveys identify law school graduates, allowing analysis of that subgroup. See Simkovic \& McIntyre, supra note 5, at 250 (using data from the U.S. Census Bureau's Survey of Income Program and Participation). Those surveys, however, do not yet include data about recent graduates.

26. John P. Heinz \& Edward O. Laumann, Chicago Lawyers: The SOCIAL STRUCTURE OF THE BAR 9 (1982).

27. John P. Heinz et al., Urban Lawyers: The New Social Structure OF THE BAR 19 (2005). 
researchers used a stratified national sample of lawyers admitted to the bar in $2000 .{ }^{28}$ To account for mobility among junior lawyers, the $A J D$ sample included both lawyers first admitted to the bar in 2000 and those moving from another state who "had graduated from law school no earlier than 1998. ${ }^{29}$

Studies that focus on bar members omit a significant portion of law school graduates: those who never take a bar exam, those who cannot pass the exam, and those who fail to gain admission on character or other grounds. This constraint affects conclusions that a study can draw about the full universe of law school graduates; I discuss those limits further below. ${ }^{30}$ The universe of bar members, however, offers an appropriate window into career outcomes for people seeking to join the traditional law profession; bar membership is a prerequisite for that work.

I based my population, therefore, on bar membership-with particular attention to the definitions used in the recent $A J D$ study. The research population in this Article consists of all new lawyers admitted to the bar after passing the February or July 2010 Ohio bar exam. Like the $A J D$ researchers, I defined "new lawyer" to include attorneys who had already been admitted to another state's bar, as long as they had graduated from law school no more than two years before their Ohio admission.

Lists of successful Ohio examinees, regularly published by the Ohio Supreme Court, established the outer population limits. A total of 1,258 applicants passed the February and July exams in 2010. ${ }^{31}$ Thirty-nine of these lawyers did not fit the definition of "new lawyer," and I excluded them from the population. Two of the successful examinees passed away before 2014, and two others were

28. AM. BAR FOUND. \& NALP FOUND. FOR LAW CAREER RESEARCH \& Educ., After the JD: First Results of a National Study of Legal Careers 89 (2004) [hereinafter AJD I].

29. Id.

30. See infra note 70 and accompanying text.

31. See Press Release, The Supreme Court of Ohio \& The Ohio Judicial Sys., More than 900 Applicants Pass July 2010 Bar Exam (Oct. 29, 2010), http://www.supremecourt.ohio.gov/PIO/news/2010/barexam_102910.asp (reporting 987 successful examinees from the July 2010 exam); Press Release, The Supreme Court of Ohio \& The Ohio Judicial Sys., Nearly 300 Applicants Pass February 2010 Bar Exam (Apr. 30, 2010), http://www.supremecourt.ohio.gov/PIO/news/2010/ barExam_043010.asp (reporting 271 successful examinees from the February exam). 
never admitted to the bar. ${ }^{32}$ After excluding these four individuals, I retained 1,214 lawyers in the research population.

Because I defined the population by bar admission, rather than law school graduation, the population includes some lawyers who completed their degrees in 2008 and $2009 .{ }^{33}$ These lawyers, however, entered the employment market for licensed attorneys at the same time as students graduating in 2010. In that sense, they are members of a "Class of 2010," and I use that label for simplicity.

Table I offers descriptive information about the population; I explore these characteristics, along with other outcomes, in Part II. ${ }^{34}$

\section{Table I \\ RESEARCH POPULATION}

$(\mathrm{N}=1,214)$

Characteristic

Percentage of

Female

Population

February Examinee

43.5

Active Status (Ohio Bar)

20.2

Active Status (Any Bar)

90.9

Current Job Requires Bar Admission

93.2

Currently in Private Practice (Solo or Firm)

Currently Working Outside Ohio

\section{B. Data Gathering}

The Ohio Supreme Court maintains a publicly accessible directory of all lawyers admitted to practice in Ohio. ${ }^{35}$ That directory

32. I found no public explanation for these two failures of admission. The applicants may have failed Ohio's character and fitness inquiry, or they may have decided to forgo the expense and paperwork of registration. Neither currently practices law in Ohio or any other state.

33. A very small number of lawyers completed their degrees even earlier but qualified for the population because they had not been admitted to any bar before 2010 .

34. The bar directory does not report gender, but I was able to deduce gender for all but one population member from names, photos, and the online biographies described below. The other population attributes summarized in Table I derive either from the Ohio bar directory or from other sources described in the next section.

35. Attorney Information Search, The Supreme Court of OHIO \& The OHio Judicial Sys., http://www.supremecourt.ohio.gov/AttySvcs/AttyReg/Public AttorneyInformation.asp (last visited Sept. 21, 2015). The search engine for this directory was particularly helpful in identifying population members who had 
confirmed the admission date for all population members. The directory also revealed bar status (active or inactive), disciplinary history, and JD school for every member of the population. ${ }^{36}$ Bar records further provided a current job title, employer, and workplace address for most population members. ${ }^{37}$ If an employer was not listed, the directory showed a residence address; that address, together with the JD school, provided an important lead in tracking population members. ${ }^{38}$

Although these bar records revealed employment information for most population members, I did not rely exclusively on that source. For lawyers who listed a current workplace, I attempted to confirm employment on the employer's website. Most law firms and government agencies list their affiliated lawyers, and many provide extensive biographies. If I could not confirm employment on the employer's site, or if the lawyer listed only a residence address in the bar records, I turned to a series of online directories and general searches for more information. ${ }^{39}$

Using these techniques, I identified an employer and job title for all but seventy-seven members $(6.3 \%)$ of the research population. All data were gathered during a six-week period from late November 2014 through early January 2015, reducing the possibility of calendar distortions. For simplicity, I refer to all employment data as stemming from December 2014.

In addition to identifying December 2014 employment, I obtained data on employment history for four-fifths $(80.1 \%)$ of the population. This information, like current job information, came from employer biographies, professional directories, and other online

changed their last names; it allows searches by first, middle, or last name. Using that feature, I was able to locate every population member.

36. Just seven of the population members had disciplinary notes at this early stage of their careers; all of these were for the administrative offense of failing to register and pay the appropriate registration fee. Six of those lawyers had cured the defect and regained their good standing; one remained inactive.

37. Ohio rules require all bar members to report both their workplace and residence addresses to the bar. Gov. BAR R. VI §§ 1(D), (F), 2(B).

38. Although Ohio bar members provide a residence address to the Supreme Court, the court publishes that address only if the lawyer neglects to list a workplace. $I d$. $\S 1(\mathrm{G})$. Residence addresses were particularly useful in tracking lawyers who had relocated to another state; JD school was invaluable in confirming identities of lawyers listed in online directories or other sources.

39. The most helpful online source was LinkedIn, a professional networking directory. See Press Release, LinkedIn, supra note 19. I purchased a premium subscription to LinkedIn, which allowed me to access directory information without drawing upon personal connections in the database. 
sources (such as newspaper articles or court pleadings). Although these data are not as complete as listings for current employment, they offer important insights into job turnover and other aspects of career advancement.

I coded data using SPSS Statistics Desktop, version 22.0. Unless otherwise specified, I used the chi-square statistic to examine associations of categorical data and a two-tailed $t$ test for independent means. All sample sizes were large enough to support these tests.

\section{Generalizability}

By focusing on a single state, I was able to gather data about almost every population member; the results paint a full picture of employment outcomes for new lawyers admitted to the Ohio bar in 2010. This focus also enabled me to describe a professional ecosystem without the distortions introduced by relying upon national averages. ${ }^{40}$ Like Heinz and Laumann's study of Chicago lawyers, ${ }^{41}$ I offer a perspective on the legal profession drawn from indepth examination of a particular community.

Although my findings cannot fully reflect outcomes in other states, three factors suggest that Ohio's legal market offers useful insights to practitioners and educators in a wide range of markets. First, Ohio itself represents a substantial legal market; it ranks ninth among states for both the size of its licensed $b^{42}$ and the number of jobs provided to recent law graduates. ${ }^{43}$ The state includes two cities (Columbus and Cleveland) that place among the top twenty cities for employing new law school graduates. ${ }^{44}$ Three of the nation's largest firms originated in Ohio and maintain substantial offices in the state: Jones Day, ${ }^{45}$ BakerHostetler, ${ }^{46}$ and Squire Patton Boggs. ${ }^{47}$ Nine other

40. For a recent discussion of this problem, see Ronit Dinovitzer \& John Hagan, Hierarchical Structure and Gender Dissimilarity in American Legal Labor Markets, 92 SOC. FORCES 929, 934 (2014).

41. See supra notes 26-27 and accompanying text.

42. Clara N. Carson, The lawyer Statistical Report: The U.S. Legal PROFESSION IN 2005270 (2012).

43. NALP, Jobs \& JDs: EMPloyment and SAlaries of NeW LAW GRADUATES, Class OF 201075 (2011) [hereinafter JoBS \& JDs 2010].

44. Id. at 74 .

45. Jones Day is the nation's second largest law firm, with 1,673 lawyers practicing in the United States as of March 2015. Jake Simpson, Law360 Reveals 400 Largest US Firms, LAw360 (Mar. 22, 2015, 4:00 PM), http://www.law360.com/articles/631981/law360-reveals-400-largest-us-firms. The 
large firms operate in Ohio, five of them with headquarters in the state. ${ }^{48}$

These law firms, however, do not dominate Ohio's legal practice in the same way that the BigLaw firms of New York and Chicago overshadow other practice opportunities in their states. At least for recent law school graduates, Ohio offers a mix of legal employers that approximates national employment patterns. Table II substantiates that fact by displaying employment patterns, nine months after graduation, for the ten jurisdictions employing the largest number of law school graduates. ${ }^{49}$ Ohio differs significantly from the national average on only one measure, business employment. Eight of the other nine states differ significantly in at least two of these job categories; five differ in all three. Ohio does not perfectly mirror national employment trends, but it is one of only two large states closely paralleling those trends.

firm originated in Cleveland and maintains almost 300 lawyers in Ohio. Cleveland, JONES DAY, http://www.jonesday.com/cleveland/ (last visited Sept. 21, 2015); see also Columbus, JONES DAY, http://www.jonesday.com/columbus/ (last visited Sept. 21, 2015).

46. BakerHostetler, like Jones Day, originated in Ohio. Baker \& Hostetler, The EnCyClopedia of Cleveland History (July 21, 1997, 1:29 PM), http://ech.case.edu/cgi/article.pl?id=BH. The firm now has fourteen offices nationally, but about a third of its 900 lawyers work in three Ohio offices. Offices, BAKERHosteTLER, http://www.bakerlaw.com/offices (last visited Sept. 21, 2015); About Us, BAKERHOSTETLER, http://www.bakerlaw.com/AboutUs/Overview (last visited Sept. 21, 2015); Professionals, BAKERHOSTETLER, http://www.bakerlaw.com /professionals (last visited Sept. 21, 2015). The firm is the twentieth largest in the United States. Simpson, supra note 45.

47. Squire Patton Boggs emerged from the merger of Squire, Sanders \& Dempsey (an Ohio-based firm), Hammonds (a United Kingdom firm), and Patton Boggs (centered in Washington, D.C.). History, SQUiRE PATTON BogGS, http://squirepattonboggs.com/about/history (last visited Sept. 21, 2015). The firm is the nation's forty-fifth largest, Simpson, supra note 45, with substantial offices in Cleveland, Columbus, and Cincinnati. Locations, SQuire PatTon Boggs, http://squirepattonboggs.com/offices (last visited Sept. 21, 2015).

48. These include WilmerHale; Littler; Barnes \& Thornburg; Frost Brown Todd; Dinsmore \& Shohl; Taft Stettinius \& Hollister; Thompson Hine; Vorys Sater; and Ice Miller. All nine of these firms employ more than 250 lawyers nationally. See Simpson, supra note 45.

49. The table includes only the three largest job categories: private practice, government, and business. JoBS \& JDs 2010, supra note 43, at 13. 
Table II

EMPLOYMENT SETTINGS FOR EMPLOYED LAWYERS

Class OF 2010 at Nine MonthS

${\text { (IN PERCENTAGES })^{50}}^{50}$

\begin{tabular}{llllr} 
& Private Practice & Government & Business & $\mathbf{N}$ \\
\hline New York & $62.8^{* *}$ & $09.2^{* *}$ & $13.9^{*}$ & 4,844 \\
\hline California & $57.6^{* *}$ & $08.7^{* *}$ & 14.4 & 3,992 \\
\hline Washington, D.C. & $36.0^{* *}$ & $34.2^{* *}$ & $09.7^{* *}$ & 2,241 \\
\hline Texas & $59.0^{* *}$ & $10.7^{* *}$ & $17.7^{* *}$ & 2,229 \\
\hline Florida & $56.0^{* *}$ & $14.3^{*}$ & $11.7^{* *}$ & 2,101 \\
\hline Illinois & $57.3^{* *}$ & $11.1^{*}$ & $17.2^{*}$ & 1,825 \\
\hline Pennsylvania & 49.7 & $08.9^{* *}$ & 15.8 & 1,190 \\
\hline Massachusetts & 49.5 & $09.5^{* *}$ & $17.7^{*}$ & 1,158 \\
\hline Ohio & 49.4 & 12.4 & $21.3^{* *}$ & 1,037 \\
\hline Virginia & $33.2^{* *}$ & $26.2^{* *}$ & 16.3 & 925 \\
\hline National & 50.9 & 12.8 & 15.1 & 36,043 \\
\hline Winin
\end{tabular}

Within each column, percentages for each state are compared to the national percentage.

$* p<.05 \quad * * p<.01$

Ohio's overall economy, finally, offers an appropriate context for judging employment opportunities for junior lawyers. Table III displays the unemployment rates, in both 2010 and 2014, for the ten states that employed the largest number of 2010 law graduates. Ohio's unemployment rate was somewhat high in 2010, but the state did not suffer as much as California or Florida; measuring lawyer employment in the latter states could skew results. More important, Ohio's 2014 unemployment rate was the third best in the group. Junior lawyers located in Ohio should have benefited from the state's relatively rapid economic recovery. New lawyers in California, Illinois, and the District of Columbia, in contrast, are struggling with weaker economic recoveries.

50. Figures in this table derive from JoBS \& JDs 2010, supra note 43, at 75 (Ohio percentages) and 13 (national percentages). 
Table III

UNEMPLOYMENT RATES

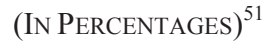

\begin{tabular}{lrr} 
& $\mathbf{2 0 1 0}$ & $\mathbf{2 0 1 4}$ \\
\hline New York & 8.6 & 6.3 \\
\hline California & 12.2 & 7.5 \\
\hline Washington, DC & 9.4 & 7.8 \\
\hline Texas & 8.1 & 5.1 \\
\hline Florida & 11.1 & 6.3 \\
\hline Illinois & 10.4 & 7.1 \\
\hline Pennsylvania & 8.5 & 5.8 \\
\hline Massachusetts & 8.3 & 5.8 \\
\hline Ohio & 10.3 & 5.7 \\
\hline Virginia & 7.1 & 5.2 \\
\hline National & 9.6 & 6.2 \\
\hline
\end{tabular}

These characteristics of the research population support cautious generalization to other legal markets. At the least, findings within this study suggest trends that are likely to touch all legal markets to some extent. Generalizability, of course, declines for other markets that depart from national averages. New York City and the District of Columbia are prominent legal markets, but they are also very unusual ones. ${ }^{52}$ Those markets differ as much from national norms as do the uncommon markets of Wyoming and Vermont. ${ }^{53}$ Even these outlier markets, however, are likely to reflect some of the trends identified in the research population.

Generalizability also affects the ability to compare findings across studies, although the latter concept differs from the former. Social scientists often compare outcomes drawn from studies that use

51. For the data in this table, see Local Area Unemployment Statistics, BUREAU OF LABOR STATISTICS, http://www.bls.gov/lau/\#tables (last modified Mar. 4, 2015) (follow hyperlinks for "2010" and "2014" under "Annual Average Statewide Data Tables: Unemployment Rates for States"). New York registered slightly lower rates than Ohio in 2010 and 2011 but climbed above Ohio after that point. Id.

52. See, e.g., JoBS \& JDs 2010, supra note 43, at 68.

53. Wyoming and Vermont offered the smallest number of nine-month jobs to members of the Class of 2010. JoBS \& JDs 2010, supra note 43 , at 75 . The job distribution in those states also varied greatly from national averages. Sixty-six percent $(66.7 \%)$ of the Wyoming jobs were in private practice, an even higher percentage than in New York. Id. Vermont, in contrast, employed only $34.0 \%$ of its newest lawyers in private practice, a percentage placing it below the District of Columbia. Id. 
different methods and examine different populations. These comparisons are inexact, but they are inevitable given the different approaches that investigators apply to social issues. In this Article, for example, I compare outcomes for the research population with information drawn from Heinz and Laumann's studies of Chicago lawyers, AJD's national findings, ABA statistics, and annual NALP reports. These sources differ from one another-and from my study - but they are widely recognized sources of information about the legal profession. With appropriate caveats, these comparisons can refine our understanding of the profession's evolution.

D. Missing Data

Drawing upon the sources described above, I obtained December 2014 employment data for $93.7 \%$ of the population members. This is a far higher rate of return than that secured by survey research. ${ }^{54}$ The missing members of my population, moreover, are "missing" in a different sense than survey nonrespondents. The Supreme Court of Ohio requires all bar members to "keep the Office of Attorney Services apprised of the attorney's current... office address and office telephone number." ${ }^{55}$ Ohio lawyers, therefore, have a professional obligation to list their current employer with the state supreme court. In addition to this professional obligation, most lawyers have incentives to provide professional information online. ${ }^{56}$ Junior lawyers have an especially strong incentive to publish information with LinkedIn or other professional directories; these sites are important sources of new clients and professional opportunities. ${ }^{57}$

Lawyers, I found, respond to these incentives by publishing a large amount of professional information online. More than threequarters of the research population $(77.6 \%)$ maintained a current

54. See Pew ReSEARCh CTR., supra note 16, at 1 (noting that the response rate for a typical telephone survey has declined from $36 \%$ in 1997 to $9 \%$ in 2012); $i d$. at 2 (investing additional resources in a telephone survey raised the response rate to $22 \%$ ). The three survey waves in $A J D$ each obtained an admirable response rate of about $50 \%$, Nelson \& Plickert, supra note 9, at 15, but even that level falls below the one achieved in this study.

55. GOV. BAR R. VI §§ 1(D), 2(B).

56. See Bonnie Booth, Lawyer Websites: The New Yellow Pages, 100 ILL. B.J. 424, 428-30 (2012); Debra Bruce, No Lawyer Left Behind: The Risks of Not Having a Website, 70 TEX. B.J. 268, 268 (2007).

57. See, e.g., Dimetria A. Jackson, Putting Social Media into Practice, 54 Orange County LaW. 7, 7 (2012). 
page on LinkedIn. Most law firms offered detailed biographies of their attorneys, and government agencies offered at least directories confirming employment.

Lawyers who do not list employment in any of these places seem unlikely to be employed. I found direct evidence to support this assumption for about one-quarter $(26.0 \%)$ of the missing population members. Some of these individuals noted on public networking sites that they were actively seeking work; others indicated that they were at home, caring for young children. Another group maintained public employment histories that ended in 2014, suggesting that they had recently left the workforce or were job hunting.

For the remaining fifty-seven lawyers ( $4.7 \%$ of the population), public sources offered no evidence about employment status. The bar directory showed only a residential address for these lawyers; they did not maintain a current LinkedIn account; and other Internet searches generated no information. Given the depth of Internet presence for most employed lawyers, I concluded that these fiftyseven lawyers - like the ones described in the previous paragraphmost likely did not hold jobs.

Four additional factors buttress this conclusion. First, the missing lawyers were significantly more likely than other population members to have chosen inactive bar status $(p<.001) .{ }^{58}$ Even if they hold other employment, this subset of missing population members cannot be practicing law. Their inactive status also suggests a more attenuated connection to the workplace.

Second, the missing lawyers were significantly more likely than the employed lawyers to be female $(p<.05) .{ }^{59}$ Other research suggests that female lawyers are both more likely to leave the workforce than men and to be unemployed if they remain within the workforce. ${ }^{60}$ This was true for the Class of 2010 nine months after

58. Twenty-six percent $(26.0 \%)$ of the missing lawyers were inactive, while just $5.5 \%$ of employed population members fell in that category. For all inactive population members, I searched several online directories to determine whether they had switched active registration to a state other than Ohio. "Inactive" lawyers were, to the best of my knowledge, inactive in any bar.

59. Women constituted more than half $(54.5 \%)$ of the missing lawyers, while they accounted for just $43.2 \%$ of the lawyers with identifiable December 2014 employment.

60. The government uses three categories to describe employment status. Individuals "with jobs are employed;" those "who are jobless, looking for a job, and available for work are unemployed;" and those "who are neither employed nor unemployed are not in the labor force." Bureau of LAB. STAT., How the 
graduation; women were more likely than men to be "seeking a job" or "not seeking." ten times more likely than men to be "not employed" seven years after graduation. ${ }^{62}$ The disproportionate number of female lawyers among the missing population members fits with an assumption that these population members were not working.

Third, the percentage of missing lawyers in the research population is consistent with the percentage of licensed lawyers that, according to the $A J D$ surveys, were not working seven to twelve years after graduation. In 2007, seven years after the $A J D$ lawyers obtained their law licenses, $5.0 \%$ reported that they were not working. ${ }^{63}$ Five years later, the percentage was $5.3 \%{ }^{64}$ The percentage of missing lawyers in the research population is somewhat higher $(6.3 \%)$, and it was measured somewhat earlier in the lawyers' careers (four years after bar admission), but it falls in the same general range. ${ }^{65}$ Given the weaker job market encountered by the Class of 2010, as well as the likelihood that non-working graduates were less likely to respond to the $A J D$ survey, $6.3 \%$ seems like a reasonable estimate for lawyers in the research population who were not working.

Finally, although a small number of missing population members may be employed, the converse is true for the population members coded as holding jobs. My research demonstrated a high

Government Measures Unemployment, http://www.bls.gov/cps/cps_htgm.htm\# concepts (last visited Sept. 21, 2015).

61. JoBS \& JDs 2010 , supra note 43 , at $47.6 .4 \%$ of women, compared to $6.1 \%$ of men were seeking a job; $3.9 \%$ of women and $2.6 \%$ of men were unemployed and not seeking employment. Id.

62. See Am. BAR Found. \& NALP Found. FOR LAw CAREer ReSEARCh \& Educ., After the JD II: Second Results from a National Study of Legal CAREERS 64 (2009) [hereinafter AJD II] (10\% of women and 1\% of men were not employed). At least in their initial reports, $A J D$ researchers have not distinguished between "not employed" lawyers who were seeking jobs and those who had left the workforce. See BUREAU OF LAB. STAT., supra note 60.

63. Rebecca Sandefur \& Robert L. Nelson, Demographic Characteristics of AJD Lawyers-A Trend Over Time, in AJD III supra note 9, at 19, 21.

64. Id.

65. The first wave of $A J D$ respondents reported a lower rate $(3.6 \%)$ of lawyers who were not employed three years after bar admission. Sandefur \& Nelson, supra note 63 , at 21 . The first survey wave, however, failed to locate one-fifth of the eligible sample members. AJD I, supra note 28 , at 89 . The missing group probably included a disproportionate number of lawyers who were not working, making the overall employment estimate unreliable. Later waves of data collection located $98 \%$ of respondents, see AJD II, supra note 62 , at 12 , providing a better estimate of the percentage of lawyers who were not working. 
rate of job turnover in this population of junior lawyers ${ }^{66}$ It is quite likely, therefore, that some "employed" population members left their positions in late 2014 and did not update online sources before I performed my search. Given the substantial size of the research population compared to the small percentage of missing members, positive errors (reporting a job when one does not exist) are likely to at least balance negative ones (assuming no job when the population member does hold one). Under these circumstances, the percentage of missing population members serves as a reasonable proxy for the true percentage of population members who were not working.

For this "not working" group, my data cannot distinguish between those who were unemployed (i.e., jobless, available for work, and actively seeking work) and those who had left the labor force ${ }^{67}$ NALP data suggest that, nine months after graduation, about two-thirds of jobless graduates are seeking work, while one-third have left the labor force. ${ }^{68}$ These proportions, however, may change by the five-year mark. My analyses do not focus on the reasons for joblessness within the research population; I focus instead on the jobs that employed members occupy ${ }^{69}$

\section{E. Study Limits}

Like all social science research, this study has limits. When interpreting data from the current research, four limits are particularly important. First, the study includes only licensed lawyers; it does not identify job outcomes for law school graduates who were never admitted to the bar. This means that the study overestimates the percentage of law school graduates working in jobs that require bar admission; conversely, it underestimates the percentage of those graduates working in jobs that do not require a

66. See infra Section II.G.

67. See Bureau of LAB. StAT., supra note 60 (explaining government definitions of employment status).

68. JoBS \& JDs 2010, supra note 43 , at 8 (2,569 jobless graduates were seeking employment, while 1,330 were not seeking). At that time, another 1,214 graduates were full-time students - a status that largely disappeared by December 2014. Id.

69. Some scholars have suggested that, when assessing the relationship between an academic program and the workplace, the traditional distinction between unemployment and "out of the workforce" is not as helpful as in other contexts. See, e.g., Burk, supra note 4, at 561. It is useful for educational institutions to know how many of their graduates are not using their degrees in the workplace, regardless of the reasons for that status. 
law license. ${ }^{70}$ Similarly, the study provides no information about the percentage of unlicensed graduates who are employed or the type of jobs they hold.

Second, the public sources underlying this study do not distinguish among full-time, ongoing employment, part-time jobs, and temporary positions. Some of the employed population members almost certainly worked part-time. Ohio authorizes part-time assistant prosecutors and public defenders, ${ }^{71}$ and some population members seemed to hold positions of that nature. Similarly, some of the "company counsel" jobs in the database appeared to be parttime. ${ }^{72}$ Small law firms, meanwhile, make many arrangements with junior attorneys. A position labeled "attorney," "associate," or "counsel" might be a full-time salaried position - or it could be an ad hoc part-time one. ${ }^{73}$ I could not reliably distinguish part-time and temporary work from other positions, so I counted all working population members as "employed." This label, however, overstates employment levels in the population. ${ }^{74}$

Third, public sources may overstate employment in other ways. Attorneys are unlikely to fabricate jobs reported publicly, ${ }^{75}$ but they may exaggerate the character of the position. A "solo practitioner," for example, may be someone who has advised a few friends on legal issues while searching for salaried work. A lawyer handling

70. For an estimate of these percentages, see infra notes 164-65 and accompanying text.

71. See Ohio Rev. Code AnN. § 120.15(B)(4) (West 2015) (assistant county public defenders "may be appointed on a full or part-time basis"); OHIO REV. CODE ANN. § 309.06(B) (West 2015) (acknowledging that both elected prosecutor and any assistant prosecutors may maintain private law practices); Supreme Court of Ohio Bd. of Comm'rs on Grievances \& Discipline, Op. 2014-2 (Aug. 8, 2014), https://www.sconet.state.oh.us/Boards/BOC/Advisory_Opinions/2014/Op_14002.pdf (discussing conflict-of-interest issues raised by part-time prosecutors).

72. One population member, for example, worked as a document reviewer for a legal process organization at the same time that he served as "transactional/corporate counsel" to a manufacturing company. He listed the latter job as his primary occupation, and I counted it as such, but it probably was not a full-time position.

73. See infra notes $115-17$ and accompanying text for further discussion of this issue.

74. AJD found that $2.8 \%$ of the Class of 2000 worked part-time in 2003. Sandefur \& Nelson, supra note 63 , at 21 . By 2007 , the percentage had risen to $7.8 \%$, and in 2012 it was $8.8 \%$. Id.

75. $C f$. Jamie Guillory \& Jeffrey T. Hancock, The Effect of LinkedIn on Deception in Resumes, 15 Cyberpsychology, Behavior, \& Soc. Networking 135, 136 (2012) (finding that subjects are less likely to lie about verifiable information in online directories like LinkedIn than on traditional resumes). 
compliance issues for a company, doing the same work that nonlawyers handle, may list himself as "counsel" to the company. Public sources allow no way to test these assertions. Among other biases stemming from this limit, the study probably overstates both the number of solo practitioners and the percentage of jobs requiring bar admission. ${ }^{76}$

Finally, the study could not gather information on some factors that are essential to a full understanding of the workplace. Most regrettable, public sources do not identify race or ethnicity so I could not track race- or ethnicity-related differences in employment patterns. Given the history of discrimination in the workplace and legal profession, it is vital to continue studying those differences whenever possible. ${ }^{77}$ Similarly, my study could not identify salary, job satisfaction, and other employment outcomes tracked in some survey research. Other scholarship needs to continue filling these gaps.

Despite these limits, this study's method demonstrates a lowcost, efficient means of gathering employment data on a sizable number of licensed lawyers. The method offers substantial promise for tracking employment outcomes for lawyers in other states and at other stages of their careers. Creating a set of complementary studies based on the current method could produce key insights into the changing legal market.

76. When coding employment, I defined the category of jobs requiring bar admission broadly. I included all judicial clerks, see NALP, supra note 3, as well as any job with the word "attorney" or "counsel" in the title. When in doubt, I searched online job descriptions for more information.

77. The $A J D$ study, for example, provides significant insights into the role of race and ethnicity in the legal profession. See Ronit Dinovitzer, David Wilkins \& Robert L. Nelson, Race and Ethnicity, in AJD III, supra note 9, at 71, 72-78. For other key research in this area, see Lempert, Chambers \& Adams, supra note 24; Bryant G. Garth \& Joyce Sterling, Exploring Inequality in the Corporate Law Firm Apprenticeship: Doing the Time, Finding the Love, 22 Geo. J. Legal Ethics 1361 (2009); Monique R. Payne-Pikus, John Hagan \& Robert L. Nelson, Experiencing Discrimination: Race and Retention in America's Largest Law Firms, 44 LAW \& SoC'Y Rev. 553 (2010); David B. Wilkins, Partners Without Power? A Preliminary Look at Black Partners in Corporate Law Firms, 2 J. FOR InST. FOR STUDY LEGAL Eтнics 15 (1999); David B. Wilkins \& G. Mitu Gulati, Why Are There So Few Black Lawyers in Corporate Law Firms? An Institutional Analysis, 84 CALIF. L. REV. 493 (1996). 


\section{RESUltS: CAREER PROGRESSION FOR THE CLASS OF 2010}

The national Class of 2010 endured a markedly poor start in the job market, as shown by the middle column of Table IV. Nine months after graduation, barely two-fifths of the graduates $(39.5 \%)$ worked as attorneys in law firms. Just over two-thirds (68.2\%) held a job that required a law license. ${ }^{78}$ Among the employed graduates, more than one in ten worked just part-time; one in twelve held a position that was both part-time and temporary. ${ }^{79}$ Almost a year after earning a professional degree, one-tenth of the class was neither working nor pursuing another degree full-time.

78. See NALP, supra note 3, for a discussion of the phrases "jobs requiring a law license," "bar admission required," "lawyering jobs," and "legal jobs." I use these phrases interchangeably.

79. JoBs \& JDs 2010, supra note 43, at 9. 
Table IV

EMPLOYMENT STATUS FOR THE Class OF 2010

(IN PERCENTAges) $^{80}$

\begin{tabular}{|c|c|c|}
\hline & $\begin{array}{r}\text { February } 2011 \\
\text { National Data } \\
\text { (NALP) } \\
\end{array}$ & $\begin{array}{r}\text { December } 2014 \\
\text { Ohio Data } \\
\text { (Research Pop.) } \\
\end{array}$ \\
\hline Jobs Requiring Bar Admission & 68.2 & 75.1 \\
\hline - Solo & 2.5 & 9.1 \\
\hline - $\quad$ Law Firm & 39.5 & 40.4 \\
\hline - Judicial Clerk & 8.1 & 2.1 \\
\hline - Other Government & 8.3 & 12.2 \\
\hline - $\quad$ Business & 4.2 & 8.0 \\
\hline - $\quad$ Public Interest ${ }^{81}$ & 4.5 & 3.1 \\
\hline - $\quad$ Academic & 1.1 & 0.2 \\
\hline Jobs Not Requiring Bar Admission & 18.0 & 18.3 \\
\hline - $\quad$ Law Firm & 2.5 & 0.2 \\
\hline - Government & 2.9 & 4.1 \\
\hline - $\quad$ Business & 9.0 & 10.8 \\
\hline - $\quad$ Public Interest & 1.4 & 1.2 \\
\hline - Academic & 2.2 & 2.0 \\
\hline Job Type Unknown ${ }^{82}$ & 1.3 & -- \\
\hline Full-Time Student ${ }^{83}$ & 3.0 & 0.3 \\
\hline Not Working & 9.5 & 6.3 \\
\hline Total & 100.0 & 100.0 \\
\hline $\mathbf{N}$ & 41,156 & 1,214 \\
\hline
\end{tabular}

80. Percentages for February 2011 are drawn from JoBs \& JDs 2010, supra note 43 , at $8,12-13,15$. Percentages for December 2014 derive from the research population.

81. Following NALP's current practice, I count public defenders under "public interest" rather than "government" in both populations. See JoBS \& JDs 2010, supra note 43, at 42. The public interest category also includes legal aid lawyers.

82. This category, which applies only to NALP data, includes graduates for whom NALP received no employment information and those for whom NALP received insufficient information to place the graduate into one of the categories in the table. This accounts for some discrepancies between the table figures and overall figures cited by NALP.

83. NALP reports full-time students separately from other graduates who are not working. This differs from the conventional approach, which counts students as "out of the workforce." Educators, however, seem to find the more nuanced distinction helpful, so I maintain it here. 
Time, unfortunately, seems to have done little to cure these ills. We have no national data on the class's fortunes since February 2011, but findings from the research population offer some insights. ${ }^{84}$ The right-hand column in Table IV summarizes that population's employment status in December 2014, as those graduates neared the fifth anniversary of law school graduation. More graduates had found work by that time, but $6.3 \%$ of the population was still not working. Almost one-fifth of the graduates worked in jobs that required no law license, even though all members of this population had passed the bar exam in 2010. The percentage of lawyers working in law firms increased less than a single percentage point, stagnating at just two-fifths of the population. The percentage of solo practitioners, in contrast, nearly quadrupled - reaching almost onetenth of the population. ${ }^{85}$

This early career pattern is notably worse than the one for the Class of 2000, the graduates tracked by $A J D$. As Table V shows, that class enjoyed better nine-month outcomes than the Class of 2010; substantially higher percentages of the Class of 2000 secured law firm jobs or other positions requiring bar admission within the first year after graduation. ${ }^{86}$ Lack of employment, conversely, was lower.

84. As explained above, the distribution of nine-month jobs in Ohio was very similar to the distribution on a national level. See supra Table II. That fact, together with other factors suggesting the representative nature of the Ohio market, makes the comparison informative. See supra Section I.C.

Other factors, of course, can distort the comparisons made in Table IV. Some observers believe that NALP reports overstate employment outcomes. See, e.g., Janine Robben, Cream and Sugar with that Law Degree? Parsing the Post-Law School Employment Numbers, OR. ST. B. Bull., Nov. 2011, at 19, https://www.osbar.org/publications/bulletin/11nov/degree.html. If that is true, then outcomes would have improved more than suggested by Table IV-although the December 2014 outcomes for Ohio graduates would be no better.

85. These outcomes are surprisingly consistent with ones reported by Benjamin Barros for 2010 and 2011 graduates of Widener Law's Harrisburg campus. See Barros, supra note 5. Like me, Barros counted graduates with unknown status as unemployed. $I d$. at 4 . Within the remaining members of his population, $78.1 \%$ held jobs requiring bar admission, 36.8\% worked in law firms, and $7.3 \%$ were solo practitioners. $I d$. at 7 . Barros's estimate of jobs requiring bar admission may be high because he includes jobs at real estate title companies. Id. at 8 . Based on my research, these jobs do not require a law license. Indeed, much title work is done by employees with less than a bachelor's degree. See Summary Report for: $23-$ 2093.00 - Title Examiners, Abstractors, and Searchers, O*NET ONLinE, http://www.onetonline.org/link/summary/23-2093.00\#Education (last visited Sept. 21, 2015).

86. Through 2000, NALP used a category of "legal" jobs rather than the more recent designation of jobs requiring bar admission. The former category was 
The Class of 2000 graduated before the mid-decade boom in law firm employment,${ }^{87}$ but the class easily outpaced job attainment for the Class of 2010.

somewhat broader, including jobs for which a JD (but not bar admission) was required. When NALP implemented this change in 2001, the percentage of employed graduates holding "bar required" jobs was $75.9 \%$, compared to $79.8 \%$ of employed graduates holding "legal" jobs the year before. NALP Bulletin, Trends in Graduate Employment (1985-2008), NALP (July 2009), http://www.nalp.org/ july09trendsgradempl. Employment overall was lower in 2001 than in 2000, id., so this four-point gap likely overstates the impact of the change. Even if one shifts a full $4 \%$ of the 2000 population to the "other job" category in Table IV, the difference between the two graduating years is substantial. For simplicity, I treat the category of "legal" jobs as equivalent to "jobs requiring bar admission" or "jobs for licensed lawyers." See also supra note 3.

87. In $2007,76.9 \%$ of graduates secured jobs that required bar admission; $55.5 \%$ of the class worked in private practice. NALP, ClASS OF 2007 NATIONAL SUMMARY REPORT 1 (2008), http://www.nalp.org/uploads/1229 natlsummary07revised.pdf. In 2008, the percentage of jobs requiring bar admission fell to $74.7 \%$, but private practice positions grew to $56.2 \%$. NALP, CLASS OF 2008 NATIONAL SUMMARY REPORT 1 (2009), http://www.nalp.org/uploads/ natlsummary2008.pdf. 
Table V

Nine-MonTH OUTCOMES

Classes OF 2000 AND 2010

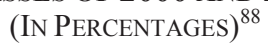

Class of 2000

Class of 2010

February 2001

February 2011

\begin{tabular}{|c|c|c|}
\hline Jobs Requiring Bar Admission & 78.0 & 68.2 \\
\hline - Solo & 1.3 & 2.5 \\
\hline - Law Firm & 48.7 & 39.5 \\
\hline - Judicial Clerk & 10.4 & 8.1 \\
\hline - Other Government & 9.7 & 8.3 \\
\hline - $\quad$ Business & 4.3 & 4.2 \\
\hline - $\quad$ Public Interest $^{89}$ & 3.4 & 4.5 \\
\hline - $\quad$ Academic & 0.2 & 1.1 \\
\hline Jobs Not Requiring Bar Admission & 10.2 & 18.0 \\
\hline - Law Firm & 0.2 & 2.5 \\
\hline - Government & 1.6 & 2.9 \\
\hline - $\quad$ Business & 7.1 & 9.0 \\
\hline - $\quad$ Public Interest & 0.3 & 1.4 \\
\hline - Academic & 1.0 & 2.2 \\
\hline Job Type Unknown ${ }^{90}$ & 3.3 & 1.3 \\
\hline Full-Time Student & 2.1 & 3.0 \\
\hline Not Working & 6.4 & 9.5 \\
\hline Total & 100.0 & 100.0 \\
\hline $\mathbf{N}$ & 34,641 & 41,156 \\
\hline
\end{tabular}

Even more striking, the Class of 2000 significantly improved its employment status during the years following graduation. $A J D$ respondents reported that more than three-fifths of them $(62.1 \%)$

88. The right-hand column of this table is identical to the middle column of Table IV and derives from the same source. See supra note 80. Figures in the middle column of this table are from NALP, JOBS \& JDS: EMPLOYMENT AND SALARIES OF New Law Graduates, Class of 2000, at 8, 12-13, 17 (2001) [hereinafter Jobs \& JDs 2000].

89. In 2000, NALP counted public defenders as government employees; by 2010 , the organization had shifted them to the public interest category. Compare JoBS \& JDs 2000, supra note 88 , at 34 , with JoBs \& JDs 2010, supra note 43, at 42. I shifted these lawyers to the public interest category for 2000 in order to ease comparison.

90. For explanation of this category, see supra note 82 . 
were practicing with a law firm by $2003 .{ }^{91}$ That percentage marks an increase of more than thirteen points from the nine-month mark. Unemployment for the class had fallen to $3.6 \%$ by 2003 , and $85.3 \%$ of the graduates worked in jobs requiring bar admission..$^{92}$ Although the U.S. economy suffered a recession in $2001,{ }^{93}$ with employment lagging through $2003,{ }^{94}$ the JD Class of 2000 significantly bettered its employment status during that period..$^{95}$

No such improvement occurred for members of the Class of 2010 licensed in Ohio. Nor, given the representative nature of the research population, is it likely that such dramatic improvement occurred in other states. Throughout the nation, current employment for the Class of 2010 more likely resembles outcomes in the research population than in the $A J D$ reports. In the remainder of this Part, I look more closely at employment outcomes for both the research population and the earlier Class of 2000.

91. Ronit Dinovitzer, Practice Setting, in AJD III supra note 9, at 25, 29. I calculated the number of respondents practicing in law firms from the "Wave 1" column, after subtracting the small percentages who worked for law firms but did not practice law. To calculate the percentage of the population, I used the total number of respondents reporting employment status (including those who were unemployed). See Sandefur \& Nelson, supra note 63, at 21 (3,824 respondents reported employment status).

92. Sandefur \& Nelson, supra note 63, at 21.

93. Press Release, Bus. Cycle Dating Comm., Nat'l Bureau of Econ. Research, Announcement of U.S. Business Cycle November 2001 Trough (July 17, 2003), http://www.nber.org/cycles/july2003.html.

94. The national unemployment rate climbed from 3.9\% in December 2000 to $6.3 \%$ in June 2003. From that peak, it declined slowly until December 2005, when the figure finally fell below $5.0 \%$. For monthly unemployment figures, see Databases, Tables \& Calculators by Subject, Unemployment, BuREAU OF LABOR STAT., http://www.bls.gov/data/\#unemployment (last visited Sept. 21 2015) (under "Labor Force Statistics including the National Unemployment Rate" select "Top Picks" and "Unemployment Rate," then adjust date range to show data from 2000 to 2015). Since late 2007, of course, unemployment has once again risen and fallen. $I d$. In December 2014, the national rate was 5.6\%-less than the rate during the period (late 2002 through early 2003) when the Class of 2000 reported job outcomes to AJD. Id.

95. AJD relied upon a different data collection method than NALP, so it is possible that this improvement resulted from biases in one or both studies. The extent of the improvement, however, suggests that employment patterns did improve noticeably for members of the Class of 2000 . 


\section{A. Law Firm Employment}

During the late twentieth century, associate positions in law firms were a mainstay of entry-level legal employment. ${ }^{96}$ In addition to providing a stable salary and benefits, these positions helped new lawyers hone their practice skills. ${ }^{97}$ In 1988, a strong hiring year, almost three-fifths of law graduates $(59.2 \%)$ obtained law firm jobs by nine months after graduation. ${ }^{98}$ That entry-level percentage fell over the next two decades, but graduates continued to secure law firm jobs as they gained one or two years of workplace experience. ${ }^{99}$ The Class of 2000, for example, expanded its percentage of law firm jobs from $48.7 \%$ (measured by NALP nine months after graduation) to $62.1 \%$ by 2003 (as reported by $A J D$ respondents). ${ }^{100}$ That gain occurred despite the recession and jobless recovery of 2001-2003. ${ }^{101}$

Opportunities for law firm employment were comparable for other lawyers graduating during the late twentieth and early twentyfirst centuries. In 2005, according to the ABA, three-fifths (59.6\%) of lawyers under the age of forty practiced law with a firm. ${ }^{102}$ Recent graduates worked in numerous other settings, but law firms provided the core employment experience for newly licensed lawyers. ${ }^{103}$

As Table $\mathrm{V}$ suggests, law firm employment dropped dramatically for the Class of 2010. Nationwide, just 39.5\% of the class practiced law with a firm nine months after graduation; that figure was almost ten percentage points lower than the one for the

96. See, e.g., Richard L. Abel, American LaWyers 221-22 (1989).

97. See id.

98. NALP Bulletin, New Grads Find More Jobs for Second Year in a Row, But Not Enough More to Offset the Larger Class Size, NALP tbl.1 (Aug. 2014), http://www.nalp.org/0814research\#table1. The table reports the percentage of the class employed and the percentage of law firm jobs. Multiplying those figures yields the percentage of graduates obtaining jobs in law firms. In 1988, as in most other recent years, NALP reported job status nine months after graduation. See supra note 21.

99. Id.

100. See supra Table V and text accompanying note 91. NALP and AJD both measured outcomes nationally, but they used different methods. It is possible that some of the job growth observed for the Class of 2000 stems from biases in one or both of these studies. The difference is strong enough, however, that it is likely to reflect a genuine shift in employment patterns.

101. See supra notes 93-95 and accompanying text.

102. CARSON, supra note 42 , at 9 (reporting that $84.6 \%$ of those lawyers were in private practice); $i d$. at 11 (reporting that $29.5 \%$ of the lawyers in private practice were solos; the remainder practiced with firms).

103. Id. 
Class of 2000. ${ }^{104}$ Even more worrisome, the percentage failed to grow as the graduates acquired more workplace experience. Four and a half years after graduation, just $40.5 \%$ of the research population practiced law with a firm. ${ }^{105}$ If Ohio outcomes parallel national averages, as they do on many other measures, ${ }^{106}$ that represents a decline of more than a third compared to the Class of 2000.

The latter gap is particularly notable because law firms have repeatedly declared their preference for associates with two to four years of experience. ${ }^{107}$ As the economy recovered, members of the Class of 2010 offered just that range of expertise. Yet law firms did not expand the number of jobs available to this pool of graduates. ${ }^{108}$

Law firm attorneys in the research population, moreover, clustered heavily in very small firms. In December 2014, almost a third of those lawyers worked in firms of just two to five lawyers. ${ }^{109}$ More than half $(56.1 \%)$ worked in firms of no more than twenty-five lawyers, and just $14.0 \%$ worked in the largest firms.

104. Both of these figures derive from NALP reports, which have made only small method changes over the years.

105. In December 2014, 492 members of the research population worked in law firms. See infra Table VI. The full population included 1,214 members. See supra Table I.

106. See supra Section I.C.

107. See, e.g., Burk, supra note 4, at 586 (recounting client refusals to pay for work by first- and second-year law firm associates); Eli Wald, Smart Growth: The Large Law Firm in the Twenty-First Century, 80 FordHAM L. Rev. 2867, 2913 (2012).

108. It is possible that the Class of 2010 gained some number of law firm jobs after February 2011 and then lost those jobs before December 2014. Almost half the Class of 2000, however, still held law firm jobs seven years after graduation. Dinovitzer, supra note 91 , at 29 . A transitory and abrupt decline so early in the careers of 2010 graduates would itself be noteworthy.

109. See infra Table VI. NALP and other sources typically report firms of 2 to 10 lawyers as a single category. I have broken that category into two groups to indicate just how small many of these firms are. A firm of two lawyers offers very different practice and mentoring opportunities to a new lawyer than one of ten. 
Table VI

Class OF 2010 OHIO LAWYERS WORKING IN LAW FIRMS, BY FIRM SIZE

(IN PERCENTAGes) $^{110}$

\begin{tabular}{lr} 
Firm Setting & December $\mathbf{2 0 1 4}$ \\
\hline 2-5 Lawyers & 31.5 \\
6-10 Lawyers & 12.2 \\
11-25 Lawyers & 12.4 \\
26-50 Lawyers & 7.1 \\
51-100 Lawyers & 5.7 \\
101-250 Lawyers & 8.9 \\
251-500 Lawyers & 8.1 \\
501+ & 14.0 \\
Unknown Size & 0.0 \\
N & 492 \\
\hline
\end{tabular}

This pattern contrasts sharply with the national pattern reported by the Class of 2000. Table VII shows the distribution of law firm attorneys by firm size for both classes several years after graduation. For the Class of 2000, almost one-third of law firm lawyers worked in a firm with more than 250 lawyers. In the Class of 2010, the Ohio percentage was $22.1 \%$ - more than eight percentage points lower. Conversely, more than half of Ohio law firm jobs for the Class of 2010 are in small firms of two to twenty lawyers; for the Class of 2000 , the percentage was $37.7 \%$ at a comparable stage in their careers.

110. All figures in this table reflect the research population. 
Table VII

LAWYERS WORKING IN LAW FIRMS, BY FIRM SIZE, ClASSES OF 2000 AND 2010

(In PerCentages) $)^{111}$

\begin{tabular}{lrr} 
Law Firm Size & $\begin{array}{r}\text { Class of 2000 } \\
\text { National Sample } \\
\text { 3 Years After JD }\end{array}$ & $\begin{array}{r}\text { Class of 2010 } \\
\text { Research Pop. } \\
\text { 4.5 Years After JD }\end{array}$ \\
\hline Law Firm (2-20) & 37.7 & 53.7 \\
Law Firm (21-100) & 19.3 & 15.2 \\
Law Firm (101-250) & 11.7 & 8.9 \\
Law Firm (251+) & 30.4 & 22.1 \\
Law Firm (Size NA) & 0.8 & 0.0 \\
N & 2,374 & 492 \\
\hline
\end{tabular}

The concentration of new lawyers in small firms is troubling for several reasons. First, graduates themselves report that they prefer other opportunities: Nine months after graduation, almost onequarter of lawyers working in these firms indicated that they were actively seeking other work. ${ }^{12}$ This was the highest percentage of job seekers for any private practice setting; even solo practitioners showed less interest in moving. ${ }^{113}$

Second, these small firms offer few mentoring opportunities for new lawyers. Within the research population, one in eight (12.3\%) of the smallest firms consisted of two or three recent graduates operating a practice together. In some cases, the 2010 graduate was the most senior lawyer in the group. These lawyers have very limited

111. Figures for the Class of 2010 are from the research population; those for the Class of 2000 derive from Dinovitzer, supra note 91, at 29. I adjusted firm categories for the research population to match available data from $A J D$. Although $A J D$ examined a national sample, while the research population focuses on Ohio, it is important to realize that a national sample includes markets that are much smaller than Ohio as well as those that are larger. $A J D$ included lawyers licensed in Tennessee, Oklahoma, Utah, and Oregon-as well as those practicing in New York City, Chicago, Los Angeles, and the District of Columbia. Strong outcomes for the Class of 2000 reflect the average of all those markets, not just outcomes in the largest markets.

112. JoBs \& JDs 2010 , supra note 43 , at 102 (reporting that $23.3 \%$ of 2010 graduates working in firms of 2 to 10 lawyers were seeking other employment).

113. Id. Lawyers employed in firms of more than 100 lawyers were less likely than those in any other setting to be seeking employment; just $4.5 \%$ of those lawyers were doing so. Id. 
experience to draw upon, both for guiding one another and for serving clients. ${ }^{114}$

Third, small firms use a variety of compensation arrangements for junior lawyers. Some pay a regular salary, but others pay their "associates" only as needed. ${ }^{115}$ The latter arrangements are more like contract employment than a conventional law firm position. ${ }^{116}$ Other small firms retain junior lawyers on an "eat-what-you-kill" basis, allowing the new lawyer to earn proceeds from their own casesoften after paying an administrative fee or percentage to the firm. ${ }^{117}$ In addition to the financial insecurity of these arrangements, they provide little incentive for the firms to mentor junior lawyers.

Even when small firms pay a regular salary, finally, the amounts are much lower than at larger firms. Three years after graduation, members of the Class of 2000 reported a median national salary of $\$ 55,000$ in firms of two to twenty lawyers. ${ }^{118}$ Graduates practicing with firms of more than 250 lawyers, in contrast, reported a median salary of $\$ 135,000 .{ }^{119}$ In addition to other impacts, this difference affects graduates' ability to repay their law school loans. Twelve years after graduation, small-firm lawyers from the Class of 2000 were less likely than graduates in larger firms to have paid off their educational debt. ${ }^{120}$ Median remaining debt was also higher for small-firm lawyers. ${ }^{121}$

At the other end of the law firm spectrum, the Class of 2010 (as reflected by the research population) held far fewer large-firm jobs than the Class of 2000. For the latter class, jobs with firms of more

114. Previous scholars have noted both the existence of small firms consisting of a few recent graduates and the difficulty of determining the prevalence of those firms. See, e.g., Campos, supra note 6, at 202; Kyle P. McEntee \& Derek M. Tokaz, Take This Job and Count It, 2 J. Legal Metrics 309, 321 (2012). This study offers the first attempt to quantify those firms.

115. See, e.g., Contract and Temporary Attorneys, Cincinnati Bar Ass'N, http://www.cincybar.org/careers/new-attorneys/contractandtemporary.php (last visited Sept. 21, 2015).

116. Id.

117. See Campos, supra note 6, at 202; Valerie L'Herrou, No Longer Extraordinary: More Humanistic, Better Client Value?, Ms. JD Blog (May 5, 2014), http://ms-jd.org/blog/article/no-longer-extraordinary-more-humanistic-betterclient-value.

118. Dinovitzer \& Wilkins, supra note 15, at 45 (columns for AJD I).

119. Id.

120. Rebecca Sandefur, Bryant G. Garth \& Joyce Sterling, Financing Legal Education-The View Twelve Years Out of Law School, in AJD III, supra note 9, at $79,83$.

121. Id. 
than 250 lawyers expanded from $26.1 \%$ of law firm jobs in February 2001 (nine months after graduation) ${ }^{122}$ to $30.4 \%$ of those jobs in 2003 (when responding to the first wave of $A J D$ surveys). ${ }^{123}$ It appears that during the first years of the century, a substantial number of law graduates moved into BigLaw jobs after the nine-month mark. ${ }^{124}$ Some of them may have practiced with small firms that merged with a larger one; others acquired experience that a BigLaw firm valued.

In contrast, BigLaw jobs seem to have contracted during the early years of the Class of 2010's careers. In February 2011, about $11.8 \%$ of the class held jobs in firms employing more than 250 lawyers. ${ }^{125}$ By December 2014, just $9.0 \%$ of the research population held those jobs. ${ }^{126}$ The decline suggests that the largest firms did not recruit a substantial number of third- and fourth-year associates to supplement reduced entry-level hiring; on the contrary, they shed lawyers with that level of experience. ${ }^{127}$

This news is particularly discouraging for graduates who hope to land BigLaw positions after gaining experience in smaller firms, government, or other settings. In the research population, I identified just thirty-nine lawyers who moved into BigLaw associate positions between February 2011 and December 2014. Nine of those lawyers followed a traditional path of completing a judicial clerkship before joining a large firm. Just thirty population members $(2.5 \%)$ managed to move from other types of employment to an associate job at a firm with more than 250 lawyers. This type of mobility was possible, but it was relatively rare.

A significant number of the 2010 graduates remaining at the very largest law firms in December 2014, finally, worked as staff

122. JoBS \& JDs 2000 , supra note 88 , at 29. In making this calculation, I removed solo practitioners from the total and calculated the percentage of jobs in the largest firms as a percentage of all law firm jobs.

123. See supra Table VII.

124. Unless otherwise noted, I use the term "BigLaw" to refer to firms with more than 250 lawyers. That usage allows the greatest flexibility in comparing percentages across data sources.

125. See JoBS \& JDS 2010, supra note 43, at 26 (reporting 4,851 class members working for firms that employed more than 250 lawyers); $i d$. at 8 (noting that employment information was available for 41,156 class members).

126. 109 population members out of 1,214 worked for firms of more than 250 lawyers in December 2014.

127. The trend identified in the research population is consistent with other reports of slowdowns in lateral hiring. See, e.g., NALP Bulletin, Lateral Hiring Slows Down for the Second Year in a Row, NALP (Mar. 2014), http://www.nalp.org/0314research (lateral hiring of associates declined in 2012 and 2013). 
attorneys rather than conventional associates. These positions have been expanding in recent years. ${ }^{128}$ Staff attorneys receive much lower salaries than traditional associates, may perform a narrower range of lawyering tasks, and are not eligible for partnership. ${ }^{129}$ Within the research population, $43.5 \%$ of graduates working at firms of more than 500 lawyers held staff attorney positions rather than associate ones. By December 2014, just 3.2\% of the research population worked as traditional associates in firms of more than 500 lawyers.

\section{B. Government and Public Interest}

The previous tables in this section separate statistics for judicial clerkships, other government positions, and public interest organizations. It is difficult, however, to make comparisons over time within those categories. Some judges have changed their hiring practices for clerkships, turning increasingly to experienced attorneys rather than new graduates. ${ }^{130}$ At the same time, employment reports vary in the way they categorize public defenders and legal aid lawyers. ${ }^{131}$ When discussing trends over time, therefore,

128. See, e.g., NALP, EMPloyment For the Class of 2013-Selected FINDINGS 3 (2014), http://www.nalp.org/uploads/Classof2013SelectedFindings.pdf (" $[\mathrm{M}]$ ore graduates are taking staff attorney or similar positions [at large law firms]."); William D. Henderson, From Big Law to Lean Law, 38 InT'L REV. L. \& ECON. 5, 8 (2014) (reporting that the number of associates in the top 250 law firms ranked by the National Law Journal fell from 60,377 to 59,574 between 2010 and 2011, while the number of "other" junior lawyers rose from 11,376 to 13,332).

129. See Henderson, supra note 128, at 8; Catherine Rampell, At WellPaying Law Firms, a Low-Paid Corner, N.Y. Times (May 23, 2011), http://www.nytimes.com/2011/05/24/business/24lawyers.html?pagewanted=all (describing emergence of staff attorneys, describing their work, and noting entrylevel salaries of $\$ 50,000$ to $\$ 65,000$ compared to salaries of up to $\$ 160,000$ for associates at the same firms); Joining as a Staff or Discovery Attorney, WILMERHALE, https://www.wilmerhalecareers.com/lawyers/joining_as_staff_ attorney/ (last visited Oct. 11, 2015) (describing training of staff and discovery attorneys, which focuses on privileges, discovery, and related matters).

130. See Sherry Karabin, Choosing the Path to Judicial Clerkship, CHICAGo LAWYER (Aug. 2011), http://www.chicagolawyermagazine.com/Archives/2011/08/ clerkstory-08-2011.aspx.

131. In 2000, NALP included legal aid lawyers in the public interest category, but counted public defenders among government workers. JoBS \& JDS 2000 , supra note 88 , at 34 . By 2010 , NALP had switched public defenders to the public interest category. JoBS \& JDs 2010, supra note 43, at 42. Publications from the $A J D$ project, meanwhile, report "legal services or public defender" as a category of its own. See, e.g., Dinovitzer, supra note 91, at 29. 
it is better to combine these categories under a single "public service" rubric.

Nine months after graduation, the Classes of 2000 and 2010 had obtained almost identical percentages of public service positions. As Table V reflects, one-quarter of each class $(25.4 \%$ of the Class of 2000, 25.2\% of the Class of 2010) worked in these jobs. ${ }^{132}$ For the Class of 2010, however, a portion of these jobs were subsidized by their law schools. Within the public interest category, for example, $42.0 \%$ of the jobs taken nationally by the Class of 2010 were shortterm ones that most likely received law school support. ${ }^{133}$

Public service jobs declined for both classes after the ninemonth mark, although my data suggest that the Class of 2010 retained marginally more of these jobs than the Class of 2000 did. In December 2014, more than a fifth $(22.7 \%)$ of the research population held public service jobs. ${ }^{134}$ For the Class of 2000, the percentages were $20.6 \%$ three years after graduation; $19.7 \%$ after seven years; and $21.8 \%$ twelve years out. ${ }^{135}$ In part, this small difference reflects greater private practice opportunities for the Class of 2000; when those jobs were available, graduates took them. The small margin, however, also indicates that government had limited capacity to absorb 2010 graduates who were unable to find jobs in other sectors.

Table VIII shows the distribution of public service jobs for the research population. As the table shows, state and local governments provided the majority of jobs in this sector. Two-thirds $(67.3 \%)$ of all public servants worked for one of those employers. Among graduates holding jobs that required bar admission, the tilt toward state and local government was even stronger: Almost three-quarters $(72.9 \%)$ of those jobs were at those levels. ${ }^{136}$

132. These percentages represent the sum of all judicial clerkship, other government, and public interest jobs reported in that table. See supra Table V.

133. JoBS \& JDs 2010, supra note 43, at 42.

134. See supra Table IV. The "public service" percentage includes all judicial clerkships, government jobs, and public interest positions reported in Table IV.

135. Dinovitzer, supra note 91, at 29. I combined the federal government, state government, legal services or public defender, and public interest categories to yield these percentages.

136. The percentage of state and local jobs is somewhat higher in Ohio than it is nationally, but these jobs outnumber federal ones in other states as well. See, e.g., JoBS \& JDs 2010, supra note 43, at 33 (reporting that for graduates employed nine months after graduation, just $39.1 \%$ of government jobs nationally were with the federal government); $i d$. at 36 (reporting that $37.8 \%$ of entry-level clerkships were with federal courts); Dinovitzer, supra note 91, at 29 (reporting that two to 
Table VIII

Distribution of Public Service Jobs

Class OF 2010 IN DECEMBER 2014

(In PerCentages) $)^{137}$

\begin{tabular}{lrrr} 
& $\begin{array}{r}\text { Bar Admission } \\
\text { Required }\end{array}$ & $\begin{array}{r}\text { Bar Admission } \\
\text { Not Required }\end{array}$ & Total \\
\hline Military & 6.9 & 2.9 & 9.8 \\
Other Federal & 9.1 & 3.6 & 12.7 \\
State & 17.0 & 3.2 & 20.2 \\
Local & 38.8 & 8.3 & 47.1 \\
Nonprofit & 4.7 & 5.4 & 10.1 \\
Total & 76.5 & 23.4 & 99.9 \\
N & 211 & 65 & 276 \\
\hline
\end{tabular}

As Table VIII illustrates, a substantial percentage of the public service jobs (23.4\%) held by the research population did not require bar admission. If Ohio outcomes represent national ones, then the Class of 2010 differs noticeably from the Class of 2000 on this measure. Three years after graduation, just $14.0 \%$ of public service employees in the Class of 2000 held jobs that did not require bar admission. ${ }^{138}$ Even seven years after graduation, when law graduates might expect to obtain key policy-making positions in government and nonprofits, just $18.5 \%$ of the public service employees from the Class of 2000 held jobs that did not require bar admission. ${ }^{139}$

The Classes of 2000 and 2010 thus held a comparable percentage of public service jobs during their early careers, but fewer of those positions required bar admission for the later class. The nonlawyering jobs taken by 2010 graduates rarely involved policymaking; instead, most population members held routine positions in human relations, compliance, contract negotiation, and case management. Population members also included a police

three years after graduation, $66.3 \%$ of public service jobs in a national sample were with state and local governments).

137. All data in this table derive from the research population.

138. See Dinovitzer, supra note 91, at 29 (Wave 1). To compute this figure, I first determined the number of "nonpracticing" jobs within each of four categories: federal government, state government, legal services or public defender, and public interest. I then calculated the percentage of those jobs within all jobs for the four identified categories. AJD's category of "nonpracticing" jobs may differ slightly from the one of "bar admission required," but the two seem largely congruent.

139. Id. (Wave 2). I calculated this figure in the same manner as for Wave 1. See supra note 138. 
officer, customer service clerk, parole officer, and government auditor.

\section{Business}

For law school graduates, jobs in "business" encompass a wide range of positions. This category includes in-house counsel, as well as lawyers who work for insurance companies, banks, or accounting firms. Lawyers employed by legal process outsourcers (LPOs) also count as "business" employees, even though their work resembles that of law firm staff attorneys. ${ }^{140}$ Businesses, finally, employ a substantial number of lawyers in positions that do not require bar admission. These jobs range from contract negotiators and compliance managers to retail sales clerks. ${ }^{141}$

NALP statistics suggest that, for jobs reported nine months after law school graduation, both the number and percentage of business jobs have grown over the last two decades. In 1993, 10.6\% of reported jobs were in business; by 2012, that percentage had jumped to $17.9 \%{ }^{142}$ Similarly, the Class of 1993 reported only 2,689 business jobs while the Class of 2012 reported 6,701. ${ }^{143}$ The progression ebbed in some years, but there is a markedly upward overall trend.

Comparing the Classes of 2000 and 2010 offers deeper insight into this growth of business jobs. As Table IX shows, $11.5 \%$ of the former class initially worked in business, while $13.2 \%$ of the latter class did so. The table further indicates that most of this increase stemmed from a rise in the number of business jobs that did not require a law license. NALP data suggest that this was an unhappy change for the Class of 2010: Almost half (45.6\%) of the 2010

140. LPOs are companies that offer specific legal services for prices below those charged by traditional law firms. Initially, LPOs focused on routine, low-end work such as document review and contract management. With experience, some of these firms are starting to perform more sophisticated legal work. See generally Regan \& Heenan, supra note 6.

141. Following NALP's practice, I characterized jobs with nonprofit medical organizations as ones with "business" rather than in "public interest." Jobs with private schools or universities, on the other hand, are counted under "academia."

142. NALP Bulletin, Jobs in Business and Industry - Two Decades of Change, NALP (Nov. 2013), http://www.nalp.org/1113research.

143. Id. 
graduates holding business jobs were seeking other work, ${ }^{144}$ compared to just $28.8 \%$ in that category a decade earlier. ${ }^{145}$

Table IX

BUSINESS JOBS OVER TIME

CLASSES OF 2000 AND 2010

(IN PeRCENTAGeS) $^{146}$

\begin{tabular}{lrrrr} 
& $\begin{array}{r}\text { Bar Admission } \\
\text { Required }\end{array}$ & $\begin{array}{c}\text { Bar Admission } \\
\text { Not Required }\end{array}$ & $\begin{array}{c}\text { Total } \\
\text { Jobs }\end{array}$ & N \\
\hline $\begin{array}{l}\text { National Class of } \\
\mathbf{2 0 0 0} \text { (9 Months) }\end{array}$ & 4.0 & 7.5 & 11.5 & 34,641 \\
$\begin{array}{l}\text { National Class of } \\
\mathbf{2 0 1 0} \text { (9 Months) }\end{array}$ & 4.2 & 9.0 & 13.2 & 41,156 \\
\hline $\begin{array}{l}\text { National Class of } \\
\mathbf{2 0 0 0} \text { (3 Years) }\end{array}$ & 4.2 & 4.1 & 8.3 & 3,684 \\
$\begin{array}{l}\text { Ohio Class of } \\
\mathbf{2 0 1 0} \text { (4.5 Years) }\end{array}$ & 8.0 & 10.8 & 18.8 & 1,214 \\
\hline
\end{tabular}

Data gathered by $A J D$, moreover, suggest that the Class of 2000 substantially reduced the number of business jobs they held during the years following graduation. After three years in the workplace, just $8.3 \%$ of the class worked in business. In particular, the class shed business jobs that did not require a law license; that percentage dropped from $7.5 \%$ to just $4.1 \%$.

Comparisons between the research population and national data are less reliable for business jobs than other work because Ohio reported a particularly high number of business jobs nine months after graduation. ${ }^{147}$ From the comparison points available, therefore, it is impossible to know how employment shifted in this sector. Table IX, however, reports the figures for the research population in December 2014: Almost a fifth of the population (18.8\%) worked in

144. JoBs \& JDs 2010, supra note 43, at 102.

145. JOBS \& JDs 2000, supra note 88 , at 102.

146. Nine-month data derive from JoBS \& JDs 2010, supra note 43, at 38 (Class of 2010), and JoBS \& JDs 2000, supra note 88, at 38 (Class of 2000). Early career data are from the research population (Class of 2010) and Dinovitzer, supra note 91, at 29 (Class of 2000). All percentages are calculated as a percentage of the graduates for whom employment status was known. Those figures appear in the far righthand column of the table.

147. See supra Table II. 
business, with a substantial number holding jobs that did not require a law license. Indeed, more than one in ten population members overall held a business job that did not require bar admission.

About half of these jobs (56.5\%) were law-related, although I stretched that definition to include even claims adjusters at insurance companies. ${ }^{148}$ Very few of the law-related jobs required a law degree; most, including those in compliance, human resources, and trust management, are jobs that non-lawyers routinely fill. ${ }^{149}$ Another fifth $(20.6 \%)$ of the non-lawyering jobs were professional ones in other fields, including medicine and engineering. The remaining positions (about $2.5 \%$ of the full population) were non-professional jobs rarely associated with law degrees. These included tennis instruction, office management, lingerie sales, and pest control. The "lawyer barista" is relatively rare, but the category is not illusory. ${ }^{150}$

\section{Academia}

Educational institutions employ just a small percentage of law school graduates. By December 2014, only twenty-six members of the research population $(2.1 \%)$ held jobs in academic institutions. Most of these graduates were compliance officers, administrative staff members, or fundraisers. Five members of the population held academic appointments at a college or university, while three worked as middle or high school teachers. Four members of the research population $(0.3 \%)$, finally, were full-time degree students.

148. Other authorities do not include adjusters in lists of law-related jobs. See, e.g., Detailed Analysis of JD Advantage Jobs, NALP (May 2013), http://www.nalp.org/jd_advantage_jobs_detail_may2013 (listing jobs for which a JD may provide an advantage).

149. See Summary Report for: 11-9199.02 - Compliance Managers, Education, O*NET ONLINE, http://www.onetonline.org/link/summary/11-9199. 02\#Education (last visited Sept. 21, 2015) [hereinafter Compliance Managers, Education] (reporting that $66 \%$ of compliance managers hold a bachelor's degree; others hold a master's degree or certificate); Summary Report for: 11-3121.00 Human Resources Managers, Education, O*NET ONLINE, http://www.onetonline. org/link/summary/11-3121.00\#Education (last visited Sept. 21, 2015) (reporting that $68 \%$ of human resources managers hold a bachelor's degree; others hold a master's degree or certificate).

150. Law school critics have used the image of graduates employed at Starbucks to denote the existence of underemployed lawyers. See, e.g., GomezJimenez v. N.Y. Law Sch., 943 N.Y.S.2d 834, 839 (N.Y. Sup. Ct.), aff'd, 956 N.Y.S.2d 54 (N.Y. App. Div. 2012). 


\section{E. Solo Practitioners}

Data from the research population suggest that the percentage of solo practitioners in the Class of 2010 grew substantially between February 2011 and December 2014. In February 2011, just 2.5\% of the class nationally reported working as a solo practitioner. ${ }^{151}$ By December 2014, 9.1\% of the research population practiced law on their own. ${ }^{152}$ That percentage translated to almost a fifth $(18.3 \%)$ of the population's private practitioners. ${ }^{153}$

Despite the romance of a solo office, it is challenging for a junior lawyer to maintain a successful practice. Attracting clients, serving their needs, and running a business are all daunting tasks for a new lawyer. ${ }^{154}$ Several indicators suggest that many of the solo offices in the research population were struggling at best-and halfhearted efforts at worst. First, half of the solos in the database $(50.9 \%)$ maintained no website or other Internet presence. Without that public face, it would be difficult for a new lawyer to attract and maintain clients. For at least some of these lawyers, the "solo practice" may have been a euphemism for jobless periods, temp work, and occasional client engagements.

Second, some of the solo practitioners noted in online biographies that they supplemented their practices with other work. Some served as part-time prosecutors, public defenders, or company counsel. ${ }^{155}$ Others combined their solo practices with jobs that did not require bar admission; these included insurance sales, investment, firefighting, party planning, and substitute teaching. ${ }^{156}$ It is impossible to tell how many of the solo practitioners worked a second job, but some of them clearly did. ${ }^{157}$

151. See supra Table IV.

152. Id.

153. Id.

154. See, e.g., Jerome E. Carlin, Lawyers on their Own: A Study of Individual Practitioners in Chicago (1962); Carroll Seron, The Business of Practicing Law: The Work Lives of Solo and Small-Firm Attorneys (1996); Burk, supra note 4, at 560-61; Campos, supra note 6, at 202; see also Lucille A. Jewel, Indie Lawyering: A New Model for Solo and Small Firm Practice, 22 Prof. LAw. 3, 4 2014, http://www.americanbar.org/content/dam/aba/administrative/ professional_responsibility/tpl_22_4.authcheckdam.pdf (acknowledging the economic risk inherent in starting a solo practice).

155. See supra notes 71-72 and accompanying text.

156. In all of these cases, I counted the graduate as a solo practitioner doing work that required bar admission.

157. Cf. HeINZ ET AL., supra note 27, at 164 (reporting that $32 \%$ of Chicago solo practitioners worked a second job in 1995). 
The data, finally, show a tendency for junior solos to close their practices in favor of other jobs. Among the population members who provided prior employment information, $7.3 \%$ had given up work as a solo practitioner. When another job became available, those lawyers closed their offices and moved on.

Given these facts, it is troubling that fully one-sixth (16.4\%) of the lawyers in the research population had worked for some time as a solo attorney, and that almost one-tenth remained in that role in December 2014. Whether these lawyers were trying to build a practice or just handling a few clients while job hunting, they were unlikely to satisfy either their own financial needs or their clients' best interests by opening a solo practice at such an early stage of their careers. ${ }^{158}$

\section{F. Jobs Requiring Bar Admission}

During the late twentieth century, most licensed attorneys practiced law. In 1975, for example, Heinz and Laumann found that $92.7 \%$ of Chicago's licensed lawyers engaged in law practice. ${ }^{159}$ Twenty years later, that percentage had fallen modestly to $88.4 \%,{ }^{160}$ but almost nine out of ten licensed attorneys still used their licenses in the workplace. ${ }^{161}$

Results from $A J D$ suggest that the Class of 2000 came close to matching those percentages, although the decline in practice jobs

158. For a new solo practitioner, notably, these two goals often conflict. The lawyer is most likely to support herself if she handles either complex cases or a high volume of simpler work. Either of these approaches, however, can overwhelm a new lawyer working on her own.

159. Heinz \& LAUMANN, supra note 26, at 9 (sample included 777 licensed lawyers); $i d$. at $16 \mathrm{n} .23$ (reporting that 57 of those lawyers were not practicing law). The 1975 sample did not include any retired or unemployed lawyers, HEINZ ET AL., supra note 27 , at 25 , so 720 lawyers out of the 777 in the sample $(92.7 \%)$ were practicing law.

160. HeINZ ET AL., supra note 27, at 19 (reporting a sample that included 787 lawyers, of whom 674 were practitioners); $i d$. at $321 \mathrm{n} .5$ (reporting that, in addition to those practitioners, 22 members of the sample were judges or judicial law clerks). Note that although the authors of the Urban Lawyers study counted judges and judicial law clerks as "nonpracticing," I have followed the more common convention of counting those lawyers as holding "practice" or "bar required" jobs.

Heinz and Laumann, of course, studied only lawyers working within Chicago's city limits - a population that may not represent lawyers nationwide. Other researchers, however, often take their findings as a baseline, and I do as well.

161. Id. at 25. About half of this decline stemmed from an increased number of retired or unemployed lawyers; the remainder represented a small increase in the percentage of lawyers holding positions that did not require a law license. Id. 
continued. Three years after graduation, $85.3 \%$ of the licensed class members were practicing law. ${ }^{162}$ The percentage fell to $78.6 \%$ in 2007 and $80.0 \%$ in 2012, but about four-fifths of the licensed lawyers continued to practice law. ${ }^{163}$

Within my research population, the percentage of lawyering jobs was still lower. Four-and-a-half years after graduation, just three-quarters $(75.1 \%)$ of those licensed lawyers were practicing law. That percentage is 10.2 points lower than the percentage reported by the Class of 2000 at a similar career point - and 17.6 points below the one described by Heinz and Laumann in 1975. Although these studies measure different populations, they suggest that the percentage of licensed lawyers doing bar-required work has been falling for some time.

Even these percentages, moreover, overstate the percentage of law graduates who obtain work requiring bar admission. Some graduates never take the bar, and others fail despite repeated tries. A conservative estimate suggests that about $12 \%$ of the Class of 2010 nationally never secured bar admission. ${ }^{164}$ Within Ohio, which had a

162. Sandefur \& Nelson, supra note 63, at 21.

163. Id.

164. Unfortunately, we have no precise measure of eventual bar passage rates nationally. Linda Wightman calculated that rate for law school graduates who took their first bar exam in 1994, LindA F. WightMAn, LSAC NATIONAL Longitudinal BAR PASSAge StUdy viii (1998) (reporting a 94.8\% eventual pass rate), but that figure is too outdated to be useful. States significantly raised bar passing scores during the $1990 \mathrm{~s}$, making subsequent pass rates at least six percentage points lower than they were in 1994. See NAT'L CONFERENCE OF BAR EXAM'RS, 2003 BAR EXAMINATION AND ADMISSION STATISTICS 16 (2004), http://www.ncbex.org/pdfviewer/?file $=\% 2 \mathrm{Fdmsdocument} \% 2 \mathrm{~F} 150$ (reporting that overall pass rates fell from $74 \%$ in 1994 to $64 \%$ in 2003); NAT'L CONFERENCE OF BAR EXAM'rs, 2013 BAR EXAMination AND AdMission Statistics 25 (2014) [hereinafter 2013 STATISTICS], http://www.ncbex.org/pdfviewer/?file=\% 2 Fdmsdocument $\% 2$ F144 (reporting that overall pass rates climbed slightly between 2003 and 2013, but stalled at 68\% in 2013); Deborah J. Merritt, Lowell L. Hargens \& Barbara F. Reskin, Raising the Bar: A Social Science Critique of Recent Increases to Passing Scores on the Bar Exam, 69 U. CIN. L. REV. 929, 929 (2001).

It is possible, however, to estimate eventual bar passage rates by combining first-time rates from one year with repeater rates from the following year. The national bar pass rate for first-time takers from ABA-accredited schools was $81 \%$ in 2010. NAT'L CONFERENCE OF BAR EXAM'RS, 2010 BAR EXAMINATION AND Admission Statistics 19 (2011) [hereinafter 2010 Statistics], http://www.ncbex.org/ pdfviewer/?file=\%2Fdmsdocument $\% 2 \mathrm{~F} 156$. The following year, the national rate for repeaters from ABA-accredited schools was 44\%. NAT'L CONFERENCE OF BAR EXAM'RS, 2011 BAR EXAMINATION AND ADMISSION STATISTICS 19 (2012) [hereinafter 2011 STATISTICS], http://www.ncbex.org/pdfviewer/?file=\% 
higher bar passage rate than the national average, the percentage is about $10 \%{ }^{165}$ Applying the latter estimate to the research population, only $67.6 \%$ of graduates from the Class of 2010 living in Ohio held lawyering jobs in December 2014. ${ }^{166}$

\section{G. Job Turnover}

The AJD authors remarked on the "high" degree of job turnover among their respondents: More than one-third changed jobs within three years of law school graduation. ${ }^{167}$ Members of my research population, however, dramatically exceeded that rate. During their first four years of practice, two-thirds of the research population switched jobs - a rate that doubled the one reported by $A J D$ for the Class of 2000. This high turnover rate, furthermore, does not include any temporary jobs that graduates pursued before they were sworn into the bar; I measured turnover only from the month of bar admission. ${ }^{168}$

2Fdmsdocument\%2F146. Combining these figures (i.e., $81 \%+[.44 \times 19 \%]$ ) yields an estimated eventual pass rate of $89.4 \%$.

This figure omits a very small number of exam takers who pass the bar two or more years after their first attempt. More important, the estimate omits graduates who never took the bar or who failed to persist after failing once. Studies suggest that the latter figure alone constitutes more than three percentage points. N.Y. Bd. OF LAW EXAM'Rs, NeW York Bar Examination Performance in FEBRUARY AND July 2006 FOR CANDIDATES FAILING THE FirST Time IN JUly 200583 (2007), http://www.nybarexam.org/press/ncberep2.pdf ("[P]ass rates increase by about 3.6 percentage points if the non-persisters are excluded from the analysis."). Estimates for the former figure-graduates who never take the bar exam-are unavailable.

To create a generous estimate of graduates admitted to the bar, I reduced my initial calculation of $89.4 \%$ to $88.0 \%$. A conservative estimate of those never admitted, conversely, is $12.0 \%$.

165. Eighty-six percent $(86 \%)$ of first-time takers from ABA-accredited law schools passed the Ohio bar exam in 2010. 2010 STATISTICS, supra note 164, at 18. The following year, $42 \%$ of repeater takers from those schools passed. 2011 STATISTICS, supra note 164, at 18. Using the method described above, supra note 164 , about $90 \%$ of law graduates living in Ohio were admitted to the bar.

166. To make this calculation, assume that the research population equals 100 lawyers. If one-tenth of graduates were not admitted to the bar (and thus did not qualify for the research population), then the full group of law graduates equals 111.1. The 75.1 population members practicing law, see supra Table IV, then constitute $67.6 \%$ of all graduates $(75.1 \div 111.1)$.

167. AJD I, supra note 28, at 53.

168. Information about career history, including job turnovers, was available for $80.1 \%$ of the population. That information appeared in employer biographies, LinkedIn, or other online sources. 
Among graduates who changed jobs after bar admission, the number of jobs ranged from two to seven. The average number of jobs for this group was 2.7, with one in six of the job changers $(16.2 \%)$ reporting four or more jobs in as many years. Among the full population, more than one in ten $(11.0 \%)$ held four or more jobs during that period.

High as those figures are, they undoubtedly understate the amount of job turnover in the research population. I obtained data on previous jobs only when individuals chose to disclose that information publicly; no website or bar authority mandates that disclosure. Lawyers have an incentive to disclose prior jobs when those positions demonstrate their experience, but they may not disclose temporary, low status, or part-time jobs. Online biographies, therefore, will tend to understate the total number of jobs a lawyer has held.

I grouped the job changers into six different categories, which are reflected in Table X. These categories compare the population member's current job to the least similar previous job. A lawyer who started as an associate at a small firm, switched to a compliance job with a manufacturer, and then moved again to join another small law firm, for example, was coded as moving from a non-lawyering job in business to a lawyering job in private practice - even though the lawyer's first and last jobs were relatively similar. This approach allowed me to detect the most substantial employment shifts.

As the table shows, the largest group of job changers (31.8\%) moved from a lawyering job to another lawyering job in a different setting. These lawyers might have shifted from a judicial clerkship to a law firm associate job; from solo practice to in-house counsel work; from a law firm to government practice; or between any other lawyering jobs in different settings. Although these lawyers practiced law for the entire period between bar admission and December 2014, they did so in at least two different settings.

The next largest group of job changers $(23.5 \%)$ shifted from a lawyering job to a non-lawyering one. This group includes, for example, law firm associates who left small firms to take jobs in compliance or mineral leasing. The category also includes bar members who moved from one non-lawyering job to another, with a brief intervening stint as a practicing lawyer. The defining characteristics of this group are that the lawyer (a) held a nonlawyering job in December 2014, and (b) had practiced law in some capacity before then. 
Table X

DisTRIBUTION OF JOB CHANGERS

Within the ReSEARCH POPUlation

(In PeRCENTAges)

Start with Lawyering Job

- Move to Another Lawyering Job in Same Setting

- Move to Another Lawyering Job in Different Setting

- Move to Non-lawyering Job

Start with Non-lawyering Job

- Move to Another Non-lawyering Job in Same Setting

- Move to Another Non-lawyering Job in Different Setting

- Move to Lawyering Job

About one-fifth of the job changers (18.3\%) moved among two or more lawyering jobs within the same setting. Most often, these lawyers shifted from one law firm to another-although some also moved within government, business, or public interest jobs. A similar percentage of job changers $(18.0 \%)$ moved from a nonlawyering job to a lawyering one. About two-fifths of those attorneys ended their transition practicing law at a firm, another third moved to lawyering jobs in government or business, and most of the remainder turned to work as solo practitioners.

Overall, the distribution in Table $\mathrm{X}$ is most notable for its lack of a coherent pattern. Members of the Class of 2010 did not move consistently from non-lawyering positions to lawyering ones, from private practice to government, or between law firms. Instead, the wide variation - combined with the high rate of turnover itselfsuggests that they are building their careers in a highly turbulent market. ${ }^{169}$

169. Contrary to some stereotypes, millennials are not more likely to switch jobs than young adults of previous generations. Data from the Bureau of Labor Statistics show that median job tenure rose among 25- to 34-year-olds between 2004 and 2014. Economic News Release, BUREAU OF LABOR STATISTICS, http://www.bls.gov/news.release/tenure.t01.htm (last modified Sept. 18, 2014). Among millennial lawyers, however, job tenure seems to be quite low. 


\section{GENDER, PRESTIGE, AND GEOGRAPHIC MOBILITY}

Career progression depends upon many factors, including the economy, educational attainment, personal motivation, and luck. ${ }^{170}$ My database supports exploration of three notable factors that have been known to influence career progression for lawyers: gender, law school prestige, and geographic mobility. ${ }^{171}$ In the Sections below, I consider each of these factors in turn, examining their relationship to career outcomes in the research population.

\section{A. Gender}

Although women have gained substantial representation within the legal profession, ${ }^{172}$ their career patterns still differ noticeably from those of men. NALP reports that nine months after graduation, men are more likely than women to work in private practice or business. ${ }^{173}$ Women, conversely, are disproportionately employed in government (including judicial clerkships), public interest, and academia. ${ }^{174}$ Female lawyers who start their careers in private practice are more likely than men to work in the largest firms, while men outnumber women in the smallest firms and solo practice. ${ }^{175}$

During the early years of the twenty-first century, these gaps in entry-level employment started to narrow. The second and third columns of Table XI illustrate that shift between the Class of 2000 and Class of 2004. The classic gender pattern persisted, but the gap

170. See Thomas W.H. Ng et al., Predictors of Objective and Subjective Career Success: A Meta-Analysis, 58 Personnel Psychol. 367 (2005) (summarizing studies and subjecting them to a meta-analysis).

171. Other factors, of course, may show equal or greater associations with career outcomes. Racial and ethnic biases, for example, have a long history in the legal profession. As noted above, however, the public nature of my sources did not allow me to code population members' racial or ethnic identity. See supra note 14. Nor did these sources contain information about socioeconomic background and other factors that are worthy of further exploration.

172. See Ronit Dinovitzer \& Bryant Garth, Lawyers and the Legal Profession, in Wiley Handbook of LaW and Society (Austin Sarat \& Patricia Ewick eds., forthcoming 2015) (manuscript at 2), http://ssrn.com/abstract=2559915 (reporting that women currently constitute $30 \%$ of all lawyers and $48 \%$ of those under age thirty).

173. NALP Bulletin, Employment Patterns-1982-2004, NALP (June 2006), http://www.nalp.org/2006junemploymentpatterns.

174. Id.

175. Id. 
was smaller in every category except public interest (a setting that employs a small percentage of graduates overall).

Table XI

EMPLOYMENT Nine MONTHS AFTER GRADUATION DifFERENCES BETWEEN MEN AND WOMEN

(In Percentage Points) $^{176}$

\begin{tabular}{lrrrr} 
& $\begin{array}{r}\text { Class of } \\
\mathbf{2 0 0 0}\end{array}$ & $\begin{array}{r}\text { Class of } \\
\mathbf{2 0 0 4}\end{array}$ & $\begin{array}{r}\text { Class of } \\
\mathbf{2 0 0 9}\end{array}$ & $\begin{array}{r}\text { Class of } \\
\mathbf{2 0 1 0}\end{array}$ \\
\hline Private Practice & 4.5 & 2.6 & 3.6 & 3.5 \\
Business & 2.7 & 2.5 & 2.3 & 2.3 \\
Judicial Clerkships & -3.7 & -2.1 & -2.2 & -1.4 \\
Government & -1.6 & 0.2 & 0.0 & -0.3 \\
Public Interest & -2.1 & -2.7 & -3.2 & -3.6 \\
Academic & -0.4 & -0.3 & -0.5 & -0.5 \\
N & 29,970 & 30,195 & 31,289 & 30,988 \\
\hline
\end{tabular}

Table XI also shows that, as the legal market tightened in 2009 and 2010, the gender gap increased again for private practice and public interest jobs. Women in the Classes of 2009 and 2010 took fewer private practice jobs and more public interest positions. Still, in the largest setting (private practice), the gap was narrower for new graduates in 2010 than in 2000.

The gender gap in the research population was considerably larger than the ones reported by NALP for recent classes, suggesting that gender differences may have grown as the Class of 2010 moved into the workforce. As Table XII shows, a gap of 8.2 points existed between the percentages of men and women working for law firms: $46.9 \%$ of men worked in that setting four years after bar admission, while just $38.7 \%$ of women did. Men, similarly, were more likely to work as solo practitioners; the gender gap was 4.0 percentage points in that setting. Women were more likely than men to work in every other setting, with the largest difference in government jobs.

176. Data for the Class of 2000 are from NALP Bulletin, Employment Comparisons and Trends for Men and Women, Minorities and Non-minorities, NALP (Apr. 2002), http://www.nalp.org/2002apremploymentcomparisons. For the Classes of 2004, 2009, and 2010, see NALP Bulletin, Employment Patterns 19992010, NALP (Aug. 2011), http://www.nalp.org/employmentpatterns1999-2010. Underlying percentages are calculated from the number of full-time jobs. 
TABLE XII

GENDER DIFFERENCES IN EMPLOYMENT SETTING

CLASS OF 2010 IN DECEMBER 2014

${\text { (IN PERCENTAGES })^{177}}^{177}$

\begin{tabular}{lrrr} 
& Men & Women & Difference \\
\hline Solo & 11.4 & 7.4 & 4.0 \\
Law Firm & 46.9 & 38.7 & 8.2 \\
Government & 17.1 & 23.0 & -5.9 \\
Business & 19.2 & 21.2 & -2.0 \\
Public Interest/Academia & 5.4 & 9.7 & -4.3 \\
N & 650 & 486 & \\
\hline
\end{tabular}

A chi-square test confirms that the job distribution in Table XII was unlikely to occur by chance $(p<.001)$. Follow-up $z$ tests of proportions indicate that men were significantly more likely than women to work in law firms $(p<.001)$ or to engage in solo practice $(p<.05)$. Women were significantly more likely to work for government $(p<.05)$ or in public interest or academic settings $(p<.01)$. For business jobs, the gender difference was not significant $(p=.414)$.

How do these gaps compare to gender differences among other lawyers with several years of workplace experience? AJD's longitudinal study of the Class of 2000 offers some insight into that question. Table XIII displays gender gaps for the Class of 2010 across seven different employment settings, together with those gaps for the Class of 2000 during all three waves of the AJD study. In four of the categories - including the large employment settings of private practice and government work - the gender gap was larger for the research population than for the Class of 2000 at any time during the latter class's first twelve years in the workforce.

The research population includes only graduates licensed in Ohio, while $A J D$ gathered data nationwide. It seems unlikely, however, that Ohio lawyers would experience greater gender gaps than the national average. Instead, the comparison suggests that gender differences are stronger for lawyers admitted to the bar in 2010 than for lawyers admitted a decade earlier.

177. All data in this table derive from the research population. 
Table XIII

GENDER GAPS OVER TIME

CLASSES OF 2010 AND 2000

(Male Percentage Minus Female Percentage) ${ }^{178}$

\begin{tabular}{|c|c|c|c|c|}
\hline & $\begin{array}{r}\text { Class of } \\
2010 \\
(4.5 \text { Years }) \\
\end{array}$ & $\begin{array}{r}\text { Class of } \\
2000 \\
(3 \text { Years }) \\
\end{array}$ & $\begin{array}{r}\text { Class of } \\
2000 \\
\text { (7 Years) } \\
\end{array}$ & $\begin{array}{r}\text { Class of } \\
2000 \\
\text { (12 Years) } \\
\end{array}$ \\
\hline Private Practice & 12.5 & 6.3 & 7.7 & 6.9 \\
\hline Federal Government & -1.5 & 0.1 & -0.8 & -0.7 \\
\hline State/Local Government & -4.4 & -4.0 & -2.5 & -2.6 \\
\hline Business & -2.3 & 2.5 & 1.3 & 1.6 \\
\hline $\begin{array}{l}\text { Legal Services/Public } \\
\text { Defender }\end{array}$ & -2.2 & -2.1 & -1.7 & -1.2 \\
\hline Public Interest & -0.1 & -1.6 & -1.5 & 0.4 \\
\hline Academia & -1.8 & -1.6 & -2.7 & -3.8 \\
\hline $\mathbf{N}$ & 1,136 & 3,637 & 3,284 & 2,271 \\
\hline
\end{tabular}

Four other notable gender distinctions emerged in the research population. First, as noted above, women were significantly more likely than men to lack published employment information $(p<.05) .{ }^{179}$ Female bar members, therefore, may have been less likely than males to hold jobs in December 2014. Second, women were significantly more likely than men to move away from Ohio. Almost one-fifth of the women (18.4\%) moved out of state after gaining bar admission, while just $14.1 \%$ of men did so $(p<.05)$. Third, among population members employed by law firms, women were significantly more likely than men to work as staff attorneys: $10.1 \%$ of the women held that status, while just $4.9 \%$ of men did $(p<.05)$. Finally, even after controlling for their employment as staff attorneys, women worked in significantly larger law firms than men; the average firm size for female private practitioners was 229.2, while for men it was $143.2(p<.01) .{ }^{180}$

178. Figures for the Class of 2010 at 4.5 years were calculated from the research population. Data for the Class of 2000 derive from the three $A J D$ waves, which are summarized in Joyce Sterling, Rebecca Sandefur \& Gabriele Plickert, Gender, in AJD III, supra note 9, at 63, 65.

179. See supra notes 59-62 and accompanying text.

180. I controlled for staff-attorney status by constructing a regression equation with gender, staff-attorney status, and school rank as independent variables; firm size was the dependent variable. All three coefficients were significant $(p<.05)$, as was the equation $(p<.001)$. The adjusted $\mathrm{R}^{2}$ was .293 . Full regression results are available upon request. 
In several other respects, gender differences were absent or attenuated. Women and men were equally likely to change jobs $(p=1.000)$; they also held a similar number of positions after doing so $(p=.535)$. Somewhat surprisingly, given the gendered pattern in employment settings, women and men did not differ significantly in whether they held jobs requiring bar admission $(p=.272)$.

Despite these points of similarity, the overall employment pattern within the research population seems strikingly gendered. Women are less likely than men to be employed, they work in significantly different settings, and they are more likely to move interstate. The latter difference is particularly noteworthy because of the difficulty junior lawyers face in transferring their licenses to a new state; most states require lawyers with less than five years of experience to retake the bar exam. ${ }^{181}$ This obstacle, together with the other differences identified in this section, suggests that gender gaps remain a concern within the legal profession. Indeed, comparisons with the Class of 2000 suggest that these gaps may be growing. If so, contemporary changes in the legal profession may undo decades of hard-won gains for women in the profession. ${ }^{182}$

\section{B. Law School Prestige}

Research consistently shows a correlation between the prestige of a lawyer's JD school and the lawyer's employment status. In their 1975 study of Chicago lawyers, Heinz and Laumann concluded "that

181. NAT'l CONFerence of Bar Exam'rs \& Am. BAR Ass'n SeCtion of Legal Educ. \& ADMISSIONS TO THE BAR, COMPREHENSIVE GUIDE TO BAR ADMISSION REQUIREMENTS 2015 34-38 (2015), http://www.americanbar.org/content/ dam/aba/publications/misc/legal_education/2015_comprehensive_guide_to_bar_ admission_requirements.authcheckdam.pdf. Fourteen states currently administer the Uniform Bar Exam, which reduces the burden of admission requirements in jurisdictions administering that exam. Id. at 32-33. Ohio, however, does not participate in that consortium. Id.

182. For further discussion of gender gaps in legal employment, including problems of promotion and pay equity, see JOHN HAGAN \& FIONA KAY, GENDER IN Practice: A Study of LAWYers' Lives (1995); NAT'L ASS'N OF WOMEN LAWYERS, Report of the Eighth Annual NAWL National Survey on Retention and Promotion of Women In LAW Firms (2014); Ronit Dinovitzer, Nancy Reichman \& Joyce Sterling, The Differential Valuation of Women's Work: A New Look at the Gender Gap in Lawyers' Incomes, 88 Soc. ForCes 819 (2009); Dinovitzer \& Hagan, supra note 40, at 938; Kathleen E. Hull \& Robert L. Nelson, Assimilation, Choice, or Constraint? Testing Theories of Gender Differences in the Careers of Lawyers, 79 Soc. ForCES 229 (2000); Fiona Kay \& Elizabeth Gorman, Women in the Legal Profession, 4 AnN. Rev. L. \& Soc. SCI. 299 (2008). 
there is a rather strict and precise correspondence between the prestige hierarchies of the suppliers of trained personnel (i.e., the law schools) and of the buyers (the employers or employment context)." "183 Graduates of the "elite" law schools, Heinz and Laumann found, disproportionately worked at the largest law firms, while graduates of "local" law schools were much more likely to work as solo practitioners. ${ }^{184}$

When Heinz and Laumann repeated their study twenty years later, they found that the prestige gap still existed but "that the representation of local schools in large firms [had] increase[d] substantially." 185 In 1995, graduates of elite schools occupied $30 \%$ of the positions in firms with more than 300 lawyers, while graduates of local schools accounted for $17 \% .{ }^{186}$ Conversely, more than half (58\%) of solo practitioners came from local law schools; just $10 \%$ of solos had graduated from an elite school. ${ }^{187}$ This pattern, the researchers concluded, suggested that prestige still mattered to employers but that the largest "firms were growing so rapidly that they found it necessary to recruit more widely." 188

The AJD study found similar correlations between law school prestige and employment outcomes for graduates of the Class of 2000. The AJD researchers used the U.S. News and World Report overall law school ranking to create five prestige categories, although they noted that this reliance "in no way indicate[d]

183. HEINZ \& LAUMANN, supra note 26, at 193.

184. Id. at 193 tbl.6.4. 31.4\% of the elite school graduates worked in firms of more than thirty lawyers, which were the largest firms of that time; just $2.0 \%$ of local school graduates worked in those firms. In contrast, $29.9 \%$ of local law school graduates - but just $7.4 \%$ of those from elite schools - served as solo practitioners. Id.

Heinz and Laumann created their own categorization of law schools, based partly on a contemporary study of law school reputation and partly on an early version of the U.S. News and World Report ranking. HEINZ ET AL., supra note 27, at 24. Their "elite" schools were the University of Chicago, Columbia, Harvard, University of Michigan, Stanford, and Yale - a group they listed in alphabetical order. Id. For their Chicago practitioners, Heinz and Laumann focused on just four "local" schools: "Chicago-Kent, DePaul, John Marshall, and Loyola[-Chicago]." Id. at 24-25. They also created categories of "prestige" and "regional" schools that fell between these two categories. Id. at 24 .

185. HEINZ ET AL., supra note 27, at 58.

186. Id. at 58 tbl.3.1.

187. Id.

188. Id. at 58 . 
endorsement of the US News approach." 189 Table XIV summarizes the relationship between those prestige categories and employment settings about three years after graduation. As the table indicates, half of employed lawyers from the top ten law schools worked in offices with more than 100 lawyers. None of those top-ten graduates worked as solo practitioners, and only $3 \%$ served in state or local government. Among graduates of fourth-tier law schools, conversely, half practiced on their own or in small firms; $17 \%$ held state or local government jobs; and just 3\% worked in the largest law offices.

\section{Table XIV \\ Job Setting by LaW School Prestige \\ CLASS OF 2000 IN 2003 \\ (IN PeRCENTAGES) $^{190}$}

\begin{tabular}{lrrrrr}
$\begin{array}{lrrr}\text { Law School } \\
\text { Rank }\end{array}$ & $\begin{array}{r}\text { Top } \\
\mathbf{1 0}\end{array}$ & $\begin{array}{r}\text { Top } \\
\mathbf{1 1 - 2 0}\end{array}$ & $\begin{array}{r}\text { Top } \\
\mathbf{2 1 - 1 0 0}\end{array}$ & Tier 3 & Tier 4 \\
\hline $\begin{array}{l}\text { Solo } \\
\text { Law Firm }\end{array}$ & 0 & 2 & 4 & 6 & 8 \\
$\begin{array}{l}\text { Office 2-20 } \\
\text { Law Firm } \\
\text { Office 21-100 }\end{array}$ & 6 & 16 & 29 & 36 & 41 \\
$\begin{array}{l}\text { Law Firm } \\
\text { Office 101-250 }\end{array}$ & 25 & 27 & 20 & 15 & 12 \\
$\begin{array}{l}\text { Law Firm } \\
\text { Office 251+ }\end{array}$ & 25 & 22 & 10 & 6 & 2 \\
$\begin{array}{l}\text { Government, } \\
\text { Federal }\end{array}$ & 7 & 11 & 5 & 3 & 1 \\
$\begin{array}{l}\text { Government, } \\
\text { State or Local }\end{array}$ & 3 & 5 & 6 & 3 & 3 \\
$\begin{array}{l}\text { Legal } \\
\text { Services/Public } \\
\text { Defender }\end{array}$ & 3 & 6 & 12 & 13 & 17 \\
$\begin{array}{l}\text { Public Interest } \\
\text { Nonprofit or }\end{array}$ & 4 & 2 & 3 & 3 & 3 \\
$\begin{array}{l}\text { Education } \\
\text { Business }\end{array}$ & 2 & 2 & 1 & 1 & 0 \\
N & 6 & 2 & 2 & 2 & 2 \\
\hline
\end{tabular}

189. AJD I, supra note 28, at 42 n.12. Instead, the researchers acknowledged, these rankings "are the most widely known, and . . . they provide a shorthand for describing clusters of schools that have reputational similarities." Id.

190. Data for this table are drawn from AJD I, supra note 28, at 44. Note that the private practice percentages in this table are for office size rather than firm size. The AJD I report does not give firm sizes. 
A similar pattern emerged within the research population. To facilitate comparison with the $A J D$ results, I adopted the same measure of law school prestige (rank in U.S. News) and created five parallel categories of schools. ${ }^{191}$ Once again, as Table XV shows, half of graduates from top-ten law schools worked as associates in firms with more than 100 lawyers, and none worked as solo practitioners. Graduates of third- and fourth-tier law schools clustered in solo practice, small firms, and state or local governments - just as they did in 2003. ${ }^{192}$

191. I used the ranking published in March 2014 because it was most contemporaneous with the employment month I studied. Elie Mystal \& Staci Zaretsky, The U.S. News 2015 Law School Rankings Are Here: Smell the Prestige, ABOVE THE LAW (Mar. 10, 2014, 8:07 PM), http://abovethelaw.com/2014/03/ the-u-s-news-2015-law-school-rankings-are-here-smell-the-prestige/. Using the ranking from March 2010, shortly before the population graduated from law school, would have made little difference. Overall, the rankings change little from year to year, especially within the broad categories used here.

Two schools tied for tenth place in the 2014 ranking; I included both in the "Top 10." Id. Similarly, three schools tied for twentieth place and I included all in the "Top 11-20" group. Id.

192. Compare Table XV, with Table XIV. 
Table XV

Job Setting by LaW School Prestige

Class OF 2010 IN DECEMBER 2014

(IN PERCENTAGES $)^{193}$

\begin{tabular}{lrrrrr} 
Law School & Top & Top & $\begin{array}{r}\text { Top } \\
\text { Rank }\end{array}$ & Tier 3 & Tier 4 \\
\hline Solo & 0.0 & 4.2 & 5.5 & 12.4 & 12.3 \\
Firm 2-20 & 8.3 & 12.5 & 18.2 & 26.3 & 27.3 \\
Firm 21-100 & 8.3 & 12.5 & 10.7 & 4.7 & 3.6 \\
Firm 101-250 & 12.5 & 8.3 & 2.9 & 4.7 & 2.4 \\
$\begin{array}{l}\text { Associate } \\
\text { Firm 251+ }\end{array}$ & 37.5 & 29.2 & 11.7 & 2.3 & 2.7 \\
$\begin{array}{l}\text { Associate } \\
\text { Firm 100+ Staff }\end{array}$ & 0.0 & 0.0 & 3.4 & 3.0 & 2.5 \\
$\begin{array}{l}\text { Att'y } \\
\text { Government, }\end{array}$ & 8.3 & 4.2 & 7.3 & 5.9 & 3.0 \\
Federal & & & & & \\
Government, & 8.3 & 0.0 & 13.8 & 15.7 & 14.5 \\
State or Local & & & & & \\
Legal & & & & & \\
Services/Public & 0.0 & 0.0 & 3.3 & 2.4 & 2.8 \\
$\begin{array}{l}\text { Defender } \\
\text { Public Interest }\end{array}$ & 4.2 & 8.3 & 1.8 & 2.4 & 1.0 \\
$\begin{array}{l}\text { Academic } \\
\text { Business }\end{array}$ & 0.0 & 0.0 & 3.4 & 2.4 & 2.5 \\
N & 12.5 & 20.8 & 17.7 & 17.8 & 25.1 \\
\hline
\end{tabular}

$A J D$ created a large category of schools ranked between 21 and 100 by U.S. News. Many observers, however, distinguish between schools in the "first tier" of the ranking (i.e., those ranked 1-50) and those in the "second tier" (ranked 51-100). To examine that distinction, Table XVI divides the middle group of AJD schools (those ranked 21-100) into two subgroups. This finer distinction shows several notable differences. The graduates from the higher ranked subgroup were more likely to work as associates in large firms and for the federal government; those in the lower ranked subgroup were more likely to work as staff attorneys in large firms, for state and local government, and in business.

193. Data in this table are drawn from the research population. To allow comparison with the $A J D$ results, I eliminated the "unemployed" category and calculated percentages based only on employed population members. I also focused exclusively on job setting, combining jobs that required bar admission with those that did not. Again, this follows the convention followed by $A J D$ in reporting correlations with law school prestige. 
Table XVI

Job Setting by Law School Prestige

CLASS OF 2010 IN DECEMBER 2014

(In Percentages) $^{194}$

\begin{tabular}{lrrrrrr} 
Law School & Top & Top & Top & Top & & \\
Rank & $\mathbf{1 0}$ & $\mathbf{1 1 - 2 0}$ & $\mathbf{2 1 - 5 0}$ & $\mathbf{5 1 - 1 0 0}$ & Tier 3 & Tier 4 \\
\hline Solo & 0.0 & 4.2 & 7.1 & 4.4 & 12.4 & 12.3 \\
Firm 2-20 & 8.3 & 12.5 & 17.4 & 18.8 & 26.3 & 27.3 \\
Firm 21-100 & 8.3 & 12.5 & 11.0 & 10.5 & 4.7 & 3.6 \\
$\begin{array}{l}\text { Firm 101-250 } \\
\text { Associate }\end{array}$ & 12.5 & 8.3 & 2.6 & 3.1 & 4.7 & 2.4 \\
$\begin{array}{l}\text { Firm 251+ } \\
\text { Associate }\end{array}$ & 37.5 & 29.2 & 14.8 & 9.6 & 2.3 & 2.7 \\
$\begin{array}{l}\text { Firm 100+ Staff } \\
\text { Att'y }\end{array}$ & 0.0 & 0.0 & 1.9 & 4.4 & 3.0 & 2.5 \\
$\begin{array}{l}\text { Government, } \\
\text { Federal }\end{array}$ & 8.3 & 4.2 & 9.0 & 6.1 & 5.9 & 3.0 \\
$\begin{array}{l}\text { Government, State } \\
\text { or Local }\end{array}$ & 8.3 & 0.0 & 12.3 & 14.8 & 15.7 & 14.5 \\
$\begin{array}{l}\text { Legal } \\
\text { Services/Public }\end{array}$ & 0.0 & 0.0 & 2.6 & 3.9 & 2.4 & 2.8 \\
$\begin{array}{l}\text { Defender } \\
\text { Public Interest }\end{array}$ & 4.2 & 8.3 & 2.6 & 2.2 & 2.4 & 1.0 \\
$\begin{array}{l}\text { Academic } \\
\text { Business }\end{array}$ & 0.0 & 0.0 & 3.2 & 3.5 & 2.4 & 2.5 \\
N & 12.5 & 20.8 & 15.5 & 19.2 & 17.8 & 25.1 \\
\hline & 24 & 24 & 155 & 229 & 338 & 366 \\
\hline
\end{tabular}

These differences underscore the pervasive correlation of law school prestige with job outcomes. Further analysis of the full research population confirmed that solo practitioners graduated from significantly lower ranked schools than other population members $(p<.001) .{ }^{195}$ For law firm associates, law school rank correlated significantly with firm size; graduates of more prestigious schools

194. Data in this table are drawn from the research population. To allow comparison with the AJD results, I eliminated the "unemployed" category and calculated percentages based only on employed population members. I also focused exclusively on job setting, combining jobs that required bar admission with those that did not. Again, this follows the convention followed by $A J D$ in reporting correlations with law school prestige.

195. Solo practitioners graduated from schools with a mean rank of 128.7, while other lawyers graduated from schools with a mean of 109.4.

For the analyses reported in this paragraph, I used the individual U.S. News rank of each school, rather than the categories reported in the table. For schools falling in the fourth, unranked quartile of the U.S. News ranking, I calculated the median fourth quartile score (171) and used that rank for all schools in the category. 
worked in larger law firms $(r=-.344, p<.001) .{ }^{196}$ Among government lawyers, those in federal positions graduated from significantly more prestigious schools than those working for state or local governments $(p<.01) .{ }^{197}$ Conversely, graduates working in jobs that did not require a law license graduated from less prestigious schools than other population members, although this difference merely approached significance in a two-tailed test $(p=.056) .{ }^{198}$ The research population thus reflects longstanding associations between law school prestige and work setting.

The population, finally, displays a growing divide among graduates who work at firms employing more than 100 lawyers. A substantial percentage of top-twenty graduates held associate positions at those firms, but they filled none of the staff attorney jobs. Graduates from the remaining schools were less likely to work as large-firm associates, but they held all of the staff attorney positions. The boundary between these lawyers is substantial; in addition to differences in pay and work assignments, most staff attorneys are ineligible to move onto the partnership track. ${ }^{199}$ Prestige hierarchies in the profession, therefore, have moved in-house to large law firms. ${ }^{200}$

\section{Geography}

Geography imposes substantial constraints on both employers and job seekers. Two-thirds of all law students seek bar admission in

196. This analysis includes only associates at those firms, not staff attorneys. The correlation persisted with staff attorneys as part of the pool, but was lower $(r=-.280, p<.001)$.

197. The mean for federal employees was 94.6, while that for state and local employees was 116.1 .

198. Lawyers working in jobs that did not require bar admission graduated from schools with a mean rank of 117.4. For other employed lawyers, the mean was 109.7 .

199. Vincent R. Johnson \& Virginia Coyle, On the Transformation of the Legal Profession: The Advent of Temporary Lawyering, 66 Notre Dame L. ReV. 359, 371 (1990); Rampell, supra note 129.

200. For other studies examining the association between law school pedigree and employment, see, e.g., Robert L. Nelson, Partners with Power: The Social Transformation of the Large Law Firm (1988); Erwin O. SMigel, The Wall Street Lawyer: Professional Organization Man? (1964); Olufunmilayo B. Arewa, Andrew P. Morriss \& William D. Henderson, Enduring Hierarchies in American Legal Education, 89 IND. L.J. 941 (2014); David Wilkins, Ronit Dinovitzer \& Rishi Batra, Urban Law School Graduates in Large Law Firms, 36 Sw. U. L. REV. 433 (2007). 
the state where they attended law school:201 three-quarters stay within the same region as that school. ${ }^{202}$ These geographic preferences, in turn, affect the candidate pools available to employers. Graduates may be willing to relocate, but only for compelling job offers.

Elite law schools, notably, are not distributed evenly across the United States; the top-twenty law schools are located within just fourteen states and the District of Columbia. ${ }^{203}$ The graduates of these schools tend to stay in-state, like other law students, or move to the biggest legal markets. ${ }^{204}$ As a result, elite school graduates cluster within relatively few states. Among graduates of the top ten schools, for example, about $60 \%$ take the bar exam in one of just four jurisdictions: New York, California, the District of Columbia, and Illinois. ${ }^{205}$ This concentration leaves remarkably few elite school graduates seeking jobs in other states.

The research population manifested all of these trends. Almost four-fifths $(78.3 \%)$ of them graduated from an Ohio law school. Another $17.1 \%$ graduated from a school located in one of the four states bordering Ohio (Michigan, Indiana, Kentucky, and West Virginia). ${ }^{206}$ Only $4.6 \%$ of the population graduated from a school

201. Where Do You Want to Work?, LAW School Transparency, http://www.lstscorereports.com/state/ (last visited Sept. 21, 2015) ("Most schools function in local markets . . : 2 in 3 employed graduates don't leave their school's state for their first job."); see also McEntee \& Tokaz, supra note 114, at 334-35.

202. JoBs \& JDs 2010, supra note 43 , at 67 (reporting that about $76 \%$ of law school graduates take jobs in the same region where they attended law school). NALP uses the U.S. Census Bureau regions for this calculation. Id. at 62. For further discussion of the relationship between geography and hiring, see Arewa, Morriss \& Henderson, supra note 200, at 1008-09; Theodore P. Seto, Where Do Partners Come from?, 62 J. LEGAL EDUC. 242, 248 (2012) ("[L]egal hiring is markedly regional, and ... most law schools are similarly regional.").

203. Mystal \& Zaretsky, supra note 191. The states are California, Connecticut, Georgia, Illinois, Massachusetts, Michigan, Minnesota, Missouri, New York, North Carolina, Pennsylvania, Tennessee, Texas, and Virginia. Id. As noted above, supra note 191, the "top-20" law schools currently include twenty-two institutions.

204. Those markets-New York City, the District of Columbia, and Chicago - accounted for $20.2 \%$ of all nine-month jobs reported by the Class of 2010 nationally. JoBS \& JDs 2010, supra note 43, at 65 (reporting 3,447 jobs in New York City; 2,241 in the District of Columbia; and 1,348 in Chicago, out of 34,895 jobs nationally).

205. I calculated this percentage from data available at $A B A$ Required Disclosures, ABA SECTION OF LegAl Educ. \& ADMissions to THE BAR, http://www.abarequireddisclosures.org/ (last visited Sept. 21, 2015) (under "Compilation - All Schools Data" select "2014" and "Bar Passage Rates").

206. The most heavily represented out-of-state school was the Salmon P. Chase College of Law at Northern Kentucky University, which is located in the 
located outside this five-state area. Most notable, only $4.1 \%$ of the research population graduated from a top-twenty law school. Nationally, those graduates constituted $16.5 \%$ of the Class of $2010 .{ }^{207}$

The percentage of elite school graduates in Ohio seems low, but it typifies most legal markets in the United States. A few cities (especially New York, Chicago, and Washington, D.C.) draw a disproportionate number of elite school graduates. ${ }^{208}$ Cities located in a few other states employ a substantial number of lawyers who graduated from a highly ranked school located in that state. ${ }^{209}$ The thirty-six states that lack either a top-twenty law school or one of the largest legal markets, conversely, employ disproportionately few elite school graduates. Even in states that attract a large number of elite graduates, those lawyers concentrate in the largest urban centers. Outside of those centers, as in most legal markets, graduates of highly ranked schools play a relatively small role.

Looking back at Tables XV and XVI, therefore, geography probably mediates part of the relationship between law school prestige and job setting. Graduates of top-ten law schools predominate in large firms partly because those firms prefer elite credentials, but also because the elite graduates are most likely to move to Ohio for those jobs. No graduates of top-twenty schools work as Ohio public defenders or legal aid attorneys, ${ }^{210}$ in part because those graduates would be less likely to move interstate for those positions. We know that some elite school graduates do seek

Cincinnati metropolitan area. That school accounted for $5.2 \%$ of the lawyers in the research population.

207. Three thousand six hundred twenty-five $(3,625)$ students graduated from the top ten law schools in 2010, while 7,203 graduated from the top twenty. Nationwide, 43,526 students graduated from ABA-accredited law schools (excluding the three Puerto Rican schools and the JAG school). For the underlying data, see ABA Required Disclosures, supra note 205 (under "Compilation - All Schools Data" select "2011" and "J.D. Enrollment and Ethnicity").

208. Id. (under "Compilation - All Schools Data" select "2014" and "Bar Passage Rates").

209. These percentages vary widely by school and state. About one-tenth of Harvard graduates take the Massachusetts bar exam, but almost two-thirds of graduates from the University of Minnesota take the Minnesota exam. See id. (explaining data source for states in which graduates took the bar exam, under "Compilation - All Schools Data" select "2011" and "J.D. Enrollment and Ethnicity").

210. See supra Table XVI. 
these jobs, ${ }^{211}$ but they are more likely to do so near the school they attended. ${ }^{212}$

To further explore the relationship between law school prestige and interstate mobility, I created dummy variables to reflect six different combinations of school prestige and geography. ${ }^{213}$ I then used these dummies as independent variables in a regression equation with law firm size as the dependent variable. ${ }^{214}$ The reference group for the dummy variables included all graduates of an Ohio school ranked 21 through 100, the largest group of graduates in the population. Since gender had shown a significant correlation with law firm size, I also included that variable in the equation.

Table XVII reports the results of this regression. Coefficients for most of the independent variables were significant, as was the equation as a whole. Taken together, the independent variables explain about $17.5 \%$ of the variance in law firm size. Graduation from a top-twenty school was associated with the largest increase in firm size; other differences in law school prestige showed more modest associations. Somewhat surprisingly, graduates of mid-range schools located outside Ohio worked in larger firms than did graduates of similarly ranked schools located in Ohio (the reference group). As explained above, however, this association does not necessarily mean that law firms preferred out-of-state graduates to in-state ones. Instead, out-of-state graduates may have been willing to move to Ohio only for jobs at somewhat larger law firms. ${ }^{215}$

211. See, e.g., AJD I, supra note 28 , at 44 (reporting that $3 \%$ of graduates from top-ten schools, as well as $2 \%$ of those from schools ranked $11-20$, worked as public defenders or legal aid lawyers three years after graduation).

212. Indeed, many of these employers hire graduates who have worked with them throughout law school. Graduates of out-of-state schools, no matter how elite, may have trouble securing entry-level jobs with these employers.

213. The six dummies represented: (a) graduation from a top-twenty school (all of which are located outside Ohio); (b) graduation from a non-Ohio school ranked 21-100; (c) graduation from an Ohio school ranked in the third tier; (d) graduation from a non-Ohio school ranked in the third tier; (e) Graduation from an Ohio school ranked in the fourth tier; and (f) graduation from a non-Ohio school ranked in the fourth tier. The missing category (graduation from an Ohio school ranked 21-100) served as my reference category.

214. I excluded staff attorneys from this analysis given the sharp differences between them and associates at the largest firms. See supra note 129 and accompanying text.

215. The coefficient for graduation from a third-tier, non-Ohio law school is not statistically significant, although the coefficient is similar in size to several other coefficients in the equation. The lack of significance stems from the small number of graduates in this particular category. The lack of significance does not mean that 
Table XVII

REGRESSION RESULTS FOR LAW FIRM SIZE

$(\mathrm{N}=567)$

Std.

\begin{tabular}{lrrrrr} 
& B & Error & Beta & $\boldsymbol{t}$ & Sig. \\
\hline Constant & 147.836 & 26.540 & & 5.570 & .000 \\
Top 20 School & 411.160 & 60.212 & .279 & 6.829 & .000 \\
$\begin{array}{l}\text { Mid-Range School } \\
\text { (Non-Ohio) }\end{array}$ & 203.891 & 56.141 & .150 & 3.632 & .000 \\
$\begin{array}{l}\text { Third Tier School } \\
\text { (Ohio) }\end{array}$ & -110.532 & 35.397 & -.146 & -3.123 & .002 \\
$\begin{array}{l}\text { Third Tier School } \\
\text { (Non-Ohio) }\end{array}$ & -136.339 & 92.681 & -.058 & -1.471 & .142 \\
$\begin{array}{l}\text { Fourth Tier School } \\
\text { (Ohio) }\end{array}$ & -139.014 & 38.324 & -.165 & -3.627 & .000 \\
$\begin{array}{l}\text { Fourth Tier School } \\
\text { (Non-Ohio) }\end{array}$ & -137.606 & 47.233 & -.125 & -2.913 & .004 \\
Female & 72.260 & 27.137 & .102 & 2.663 & .008 \\
\hline
\end{tabular}

Adjusted $R^{2}=.175$

$F=\mathbf{1 8 . 1 6 8}$

Significance of $F=.000$

The research population yielded one final insight into the interaction of geography and law school prestige: Even when hiring dropped at the largest firms from 2009 to 2010, graduates from topranked law schools did not move to Ohio in search of jobs. On the contrary, those graduates constituted only $4.1 \%$ of recent graduates admitted to the Ohio bar in 2010. Indeed, as Table XVIII shows, the percentage of top-twenty graduates taking and passing the Ohio bar declined after 2007. Weaknesses in the Ohio employment market, therefore, reflect local trends - not a cascade effect from cutbacks in larger markets. ${ }^{216}$ The same is probably true in other markets around

graduates of third-tier schools outside Ohio worked in the same size firms as graduates of mid-range firms in Ohio. It means simply that the number of graduates in the former category is too small to draw reliable conclusions.

216. A "cascade effect" occurs in a labor market when workers from one rung of the market displace workers on the rung below them, who in turn displace workers on a still lower rung. See, e.g., Jeffreys v. Commc'ns Workers of Am., AFL-CIO, 354 F.3d 270, 274 (4th Cir. 2003) (noting "cascade effects" that would result from a union's interpretation of collective bargaining agreement).

The percentage of top-twenty graduates in Table XVIII is slightly higher than in the research population because this table includes senior lawyers who took the bar exam. I excluded those lawyers from the research population if they graduated from law school before 2008 and had already joined another state's 
the country: Graduates of top-ranked law schools are attractive to employers, but they constitute a small percentage of most hiring markets.

\section{Table XVIII \\ GRADUATES OF TOP-TWENTY \\ LAW SCHOOLS PASSING THE OHIO BAR EXAM ${ }^{217}$}

\begin{tabular}{lrr} 
Year & Number & Percentage of All Passers \\
\hline $\mathbf{2 0 0 7}$ & 87 & 6.5 \\
$\mathbf{2 0 0 8}$ & 57 & 4.4 \\
$\mathbf{2 0 0 9}$ & 54 & 4.4 \\
$\mathbf{2 0 1 0}$ & 62 & 4.9 \\
$\mathbf{2 0 1 1}$ & 71 & 5.7 \\
$\mathbf{2 0 1 2}$ & 59 & 4.8 \\
$\mathbf{2 0 1 3}$ & 71 & 5.6 \\
$\mathbf{2 0 1 4}$ & 55 & 4.6 \\
Average & $\mathbf{6 4 . 5}$ & $\mathbf{5 . 1}$ \\
\hline
\end{tabular}

\section{DISCUSSION}

Data from the research population strongly suggest that structural changes are reshaping the legal profession. Five findings in particular support that conclusion. First, as the research population neared the fifth anniversary of law school graduation, their overall employment picture was almost as constricted as national employment patterns were nine months after graduation. ${ }^{218}$ Economic recovery did not substantially affect employment patterns for the research population, and neither did the accumulation of workplace experience. If the class's drop in nine-month employment stemmed

bar. See supra paragraph preceding note 40. The figures in Table XVIII report percentages for all lawyers who took the bar exam each year.

217. Data from this table are drawn from lists published by the Ohio Supreme Court. See Ohio Bar Examination, Supreme Court of OHIO, http://www.supremecourt.ohio.gov/AttySvcs/admissions/barExam.asp (last visited Sept. 21, 2015) (select years "2007" through "2014" under "Bar Examination Law School Tabulations"). To designate the "top 20" law schools, I used the same measure discussed above. See supra note 192. Although that list stems from a single 2014 ranking, membership in the top group of law schools changes little from year to year. $I d$.

218. See supra Table IV (summarizing employment outcomes for the research population); Table V (summarizing nine-month employment outcomes for the national Class of 2010). 
primarily from the recession, the research population should have improved its employment outcomes further by this point.

Second, these findings contrast sharply with job attainment for the Class of 2000. That class, according to the AJD study, considerably improved its employment pattern while weathering a recession. ${ }^{219}$ The 2001 recession was much milder than the Great Recession, but both featured jobless recoveries in which employment rates lagged other measures. ${ }^{220}$ In late 2002 and early 2003, when the Class of 2000 responded to the first wave of $A J D$ surveys, the national unemployment rate stood at 5.8\%-6.0\%. ${ }^{221}$ Despite that relatively high rate, the Class of 2000 found sizable opportunities within the legal profession. So far, at least, economic recovery has not brought similar relief to the members of the research population; although Ohio's unemployment rate was just 5.7\% in December 2014 , the population's employment pattern remained lackluster. ${ }^{222}$

Third, although every member of the research population holds a law license, only three-quarters of them use that license in the workplace. This percentage represents the most recent low point of a trend that started well before the Great Recession, ${ }^{223}$ suggesting that it reflects developments within the profession itself. The percentage itself is startling: At least one-quarter of newly licensed lawyers are not using licenses that they invested substantial time and money to obtain. When estimated as a percentage of all law school graduates, including those who never took or passed the bar, the figure is an even more remarkable one-third. ${ }^{224}$

219. See supra notes 91-92 and accompanying text.

220. See supra note 94 and accompanying text.

221. For the monthly unemployment rates, see Databases, Tables \& Calculators by Subject, Unemployment, BUREAU OF LABOR STAT., http://www.bls.gov/data/\#unemployment (last visited Sept. 21 2015) (under "Labor Force Statistics including the National Unemployment Rate" select "Top Picks" and "Unemployment Rate").

222. See supra Table III. It is possible that the general recovery has yet to reach 2010 law school graduates; unemployment rates were much higher between 2008 and 2014 than at any time during the first years of the century. Databases, Tables \& Calculators by Subject, supra note 221. By December 2014, moreover, the rate had been below $6.0 \%$ for only four months. $I d$. For that reason, I rely on this indicator as just one of five factors suggesting structural changes in the profession. The comparison between the two classes, however, is striking; the Class of 2010 seems to have lost, not only initial placements, but an important opportunity to advance those first jobs during the early career.

223. See supra Section II.F.

224. See supra note 166 and accompanying text. 
Fourth, law firm employment has dropped dramatically-even for lawyers with several years of post-graduate experience. Almost five years after graduation, only $40.5 \%$ of the research population works for a law firm; ${ }^{225}$ at a comparable stage in their careers, $62.1 \%$ of the national Class of 2000 held those positions. ${ }^{226}$ There is no reason to think that Ohio differs significantly from national averages on this measure; even if some variation exists, it is unlikely to explain such a large difference. An employment drop of almost twenty-two percentage points in this core workplace signals substantial changes in the legal market. The change, furthermore, is affecting lawyers with several years of experience - not just lawyers still gaining a foothold in the market.

Results from the research population, finally, suggest that the changes sweeping the legal profession are affecting employment in all work settings, not just at the largest firms in the biggest markets. As those firms reduced entry-level hiring, graduates of elite schools might have moved to other markets, displacing graduates from lower-ranked local schools. This, however, did not happen; the percentage of top-twenty graduates moving to Ohio has remained small; just $4.1 \%$ of the research population graduated from those schools. Weaknesses in the legal employment market appear to be systemic, affecting jobs in all states directly.

What are these forces that have disrupted the legal market? What do they, combined with the data from this study, suggest about job prospects for recent law school graduates and about the economics of legal education? I explore both of those questions briefly in the Sections below.

\section{A. Disruptive Forces in the Legal Market}

At least six forces are realigning the market for legal services: (1) deregulation of the profession; (2) adoption of labor-saving technology; (3) disaggregation of legal tasks; (4) increased reliance on non-lawyers for legal work; (5) competition from global providers; and (6) a persistent oversupply of licensed lawyers. Other scholars and practitioners have analyzed these forces at length; I will

225. See supra note 105 and accompanying text.

226. See supra note 91 and accompanying text. 
not repeat those discussions here. ${ }^{227}$ Instead, I highlight a few key facts about each force.

\section{Deregulation}

During the late twentieth century, a series of court rulings, cultural shifts, and economic pressures lowered the barriers that shield lawyers from competition. ${ }^{228}$ Those changes reduced income for solo practitioners and small-firm lawyers, ${ }^{229}$ transferred legal business to accountants and title companies; ${ }^{230}$ and laid the foundation for online companies that offer customized legal documents to small businesses and individual consumers. ${ }^{231}$

The market is still absorbing the full impact of these changes, but further deregulation is already on the way. The Washington Supreme Court recently authorized "Limited License Legal Technicians" (LLLTs) to assist clients with some types of legal issues. ${ }^{232}$ Other states are monitoring this development and may follow suit. ${ }^{233}$ Australia, England, and Wales, meanwhile, now permit

227. For some of the leading works in this area, see THOMAs D. MORGAN, The VANishing American LAWYer (2010); Richard Susskind, The END OF LAwyers? Rethinking the NAture of Legal Services (2010); Richard Susskind, TOMORRow's LAWYERs: An INTRODUCTION to YOUR FutURE (2013); Benjamin H. Barton, A Glass Half Full Look at the Changes in the American Legal Market, 38 InT'L REV. L. \& ECON. 29 (2014); Henderson, supra note 6; Herbert M. Kritzer, The Future Role of "Law Workers": Rethinking the Forms of Legal Practice and the Scope of Legal Education, 44 ARIz. L. REV. 917 (2002); John O. McGinnis \& Russell G. Pearce, The Great Disruption: How Machine Intelligence Will Transform the Role of Lawyers in the Delivery of Legal Services, 82 FORDHAM L. REV. 3041 (2014); Regan \& Heenan, supra note 6; Ray Worthy Campbell, The End of Law Schools: Legal Education in the Era of Legal Service Businesses, Miss. L.J. (forthcoming), http://papers.ssrn.com/sol3/papers.cfm?abstract_id=2530051.

228. See HEINZ ET AL., supra note 27, at 280-81; MorgAN, supra note 227.

229. HEINZ ET AL., supra note 27, at 162-67.

230. See Stephen Gillers, A Profession, if You Can Keep It: How Information Technology and Fading Borders Are Reshaping the Law Marketplace and What We Should Do About It, 63 Hastings L.J. 953, 1010 (2012).

231. Barton, supra note 227, at 32-34.

232. Limited License Legal Technicians, WASh. STATE BAR Ass'N, http://www.wsba.org/licensing-and-lawyer-conduct/limited-licenses/legal-

technicians (last visited Sept. 21, 2015); see generally Brooks Holland, The Washington State Limited License Legal Technician Practice Rule: A National First in Access to Justice, 82 Miss. L.J. SUPRA 75 (2013), http://mississippilawjournal.org/ wp-content/uploads/2014/11/Holland_82MissLJSupra075.pdf.

233. See Holland, supra note 232 , at 119-21; Laura Ernde, State Bar to Look at Limited-Practice Licensing Program, CAL. B.J. (Feb. 2013), http://www.calbarjournal.com/February2013/TopHeadlines/TH1.aspx. 
lawyers to share profits with non-lawyers; legislators adopted this rule to encourage competition in the market for legal services. ${ }^{234}$ Most U.S. jurisdictions have resisted this proposal, but pressure from both policymakers and clients may force this change. ${ }^{235}$

\section{Technology}

Three-fifths of law firm managing partners acknowledge that their firms have increased efficiency by substituting technology for human workers. ${ }^{236}$ An even higher percentage (84.3\%) agree that "[t]echnology replacing human resources" is a permanent trend in law practice. ${ }^{237}$ Although technology enriches the work of experienced lawyers, it reduces the need for lower skilled attorneys. $^{238}$

Humans, moreover, tend to underestimate the speed of technological advances. Both computing power and software applications improve exponentially; as a result, the impact of technology accelerates once it gains a foothold within an industry. ${ }^{239}$ "[C]omputers," John McGinnis and Russell Pearce recently warned, "may be able to undertake complicated legal tasks relatively sooner than it initially took [them] to do simpler legal tasks. ${ }^{240}$ Computer programs that conduct discovery, generate customized documents, perform legal research, and write briefs are already developing. ${ }^{241}$ None of these programs will operate without human supervision, but

234. Steve Mark, Views from an Australian Regulator, 2009 J. Prof. LAW. 45; Laura Snyder, Flexing ABS, 101 ABA J. 62 (2015). But cf. Andrew M. Perlman, Towards the Law of Legal Services (Suffolk Univ. Law Sch. Legal Studies Research Paper Series, Research Paper No. 15-5, 2015), http://ssrn.com/abstract=2561014 (questioning whether these changes will have their intended effect on competition and access to justice).

235. See Stephen Gillers, How to Make Rules for Lawyers: The Professional Responsibility of the Legal Profession, 40 PEPP. L. REV. 365, 396-403 (2013) (noting both resistance and pressure for change); Gillian K. Hadfield, The Cost of Law: Promoting Access to Justice Through the (Un)corporate Practice of Law, 38 INT'L REV. L. \& ECON. 43, 44 (2014) (arguing that change is essential for promoting access to justice).

236. Altman Weil, InC., 2015 Law Firms in Transition: An Altman Weil FLASH SURVEY 55 (2015), http://www.altmanweil.com/dir_docs/resource/1c789ef25cff-463a-863a-2248d23882a7_document.pdf. The survey included leaders of law firms with fifty or more lawyers. $I d$. at i.

237. Id. at 1 .

238. Id. at 21 .

239. See McGinnis \& Pearce, supra note 227, at 3046.

240. Id.

241. Id. at 3046-55. 
they will require many fewer lawyers than these tasks demand today. ${ }^{242}$

\section{Disaggregation}

During the early years of the twenty-first century, businesses began to subject their legal departments to the same cost and efficiency metrics that they apply to other units. ${ }^{243}$ This approach, together with supportive technology, allowed companies to unbundle legal tasks and assign them to the lowest-cost employees capable of performing each piece of work. ${ }^{244}$ When law firms were slow to follow this trend, a cadre of legal process outsourcers (LPOs) emerged to provide disaggregated services to corporate clients. ${ }^{245}$

Today, both corporations and law firms enthusiastically embrace the disaggregation of legal work. Corporations are increasing the percentage of their legal budgets allocated to LPOs; over the last two years, that percentage grew from $3.9 \%$ to $7.1 \% .{ }^{246}$ Three-quarters of the largest law firms (those with more than 250 lawyers) use contract lawyers, the same percentage employ staff attorneys, and 9.2\% outsource legal work. ${ }^{247}$ Mid-sized firms (with 50-250 lawyers) are following the lead of larger firms; about half of the mid-sized firms $(48.6 \%)$ use contract lawyers, a third (33.5\%) employ staff attorneys, and 3.3\% have outsourced legal work. ${ }^{248}$

As Ray Worthy Campbell has noted, disaggregation can offer both quality and value to clients. ${ }^{249}$ Dedicated discovery workers, for example, begin to identify patterns of document organization within

242. Id. For further discussion of computer applications in law, see Daniel Martin Katz, Quantitative Legal Prediction-or-How I Learned to Stop Worrying and Start Preparing for the Data-Driven Future of the Legal Services Industry, 62 EMORY L.J. 909, 936 (2013); Harry Surden, Machine Learning and Law, 89 WASH. L. REV. 87, 101-14 (2014).

243. See, e.g., John S. Dzienkowski, The Future of Big Law: Alternative Legal Service Providers to Corporate Clients, 82 FordHAM L. REV. 2995, 2999 (2014); Regan \& Heenan, supra note 6, at 2138.

244. See Regan \& Heenan, supra note 6, at 2149.

245. Id. at 2150-51; Campbell, supra note 227, at 44; see also supra note 140 and accompanying text (describing LPOs).

246. Georgetown Law Ctr. For the Study of the Legal Profession \& Thomson Reuters Peer Monitor, 2015 Report on the State of the Legal MARKET 8 (2015) [hereinafter 2015 REPORT], http://www.law.georgetown.edu/ academics/centers-institutes/legal-profession/upload/FINAL-Report-1-7-15.pdf.

247. Altman WeIL, INC., supra note 236, at 27.

248. Id.

249. Campbell, supra note 227, at 28. 
companies, making them more effective than associates who engage more sporadically in discovery work. ${ }^{250}$ Given the success of disaggregation, Georgetown Law's Center for the Study of the Legal Profession recently concluded that "it seems unlikely ... these shifts in buying habits will be reversed anytime soon. Indeed, it seems more likely that they will expand."251

\section{Compliance and Other Law-Related Work}

Government regulation has become so pervasive that both businesses and individuals have learned to cope without lawyers. ${ }^{252}$ Compliance officers, human resource specialists, accountants, social workers, and many other employees regularly interpret the law, even though they lack legal degrees or law licenses. ${ }^{253}$ All indicators suggest that this law-related work will continue to grow, ${ }^{254}$ and that non-lawyers will continue to dominate these fields. ${ }^{255}$

Non-lawyers have succeeded in this work both because they cost less than lawyers and because they possess expertise that lawyers lack. As Campbell points out, much contemporary regulation requires little knowledge of the broad legal principles taught in law school. ${ }^{256}$ Instead, clients benefit from deep knowledge of the regulated industry, combined with "command of chapter and verse of the relevant regulations." ${ }^{257}$ Non-lawyers usually possess more industry knowledge than lawyers, and they can learn the relevant rules through focused training. ${ }^{258}$ These non-lawyers, furthermore, often have skills that lawyers lack; effective compliance officers and human resource specialists don't merely interpret the

250. Id. at 51.

251. 2015 REPORT, supra note 246, at 8; see also Burk, supra note 4, at 58486.

252. See generally Campbell, supra note 227, at 4-5.

253. Id. at 45 .

254. See generally Michele DeStefano, Compliance and Claim Funding: Testing the Borders of Lawyers' Monopoly and the Unauthorized Practice of Law, 82 Fordham L. ReV. 2961 (2014); Tanina Rostain, The Emergence of "Law Consultants," 75 FordHAM L. REV. 1397 (2006).

255. See supra notes 85, 149 (reporting educational background of workers in these areas).

256. Campbell, supra note 227 , at 43 .

257. Id.

258. Id. 
law for their companies; they build institutional structures and cultures that foster lawful conduct. ${ }^{259}$

\section{Global Competition}

Although the hiring of law school graduates is largely local, competition for legal services is increasingly global. Multinational clients employ law firms in many countries; if United States lawyers do not meet their needs, they can shift their primary counsel to a foreign firm. ${ }^{260}$ Those firms are particularly attractive to corporate clients because they combine legal, accounting, and management services in a single organization - a feature that United States law forbids. ${ }^{261}$ Legal process outsourcers in low-wage countries, meanwhile, continue to provide document review, contract preparation, and intellectual property services at prices below those charged by domestic companies. ${ }^{262}$ These global competitors both absorb part of the market for low-level legal services and impose a lid on domestic prices.

\section{Oversupply of Lawyers}

An oversupply of licensed lawyers has been mounting for decades. The number of licensed lawyers in the United States more than doubled between 1951 and 1980, from 221,605 to 542,205. ${ }^{263}$ Over the next twenty-five years, the number more than doubled again, reaching $1,171,555$ by $2005 .{ }^{264}$ Although the nation's population also increased, the ratio of non-lawyers to lawyers steadily decreased from 695:1 in 1951 to $252: 1$ in $2005 .{ }^{265}$

259. Id. at 50 .

260. See Gary A. Munneke, Managing and Marketing a Practice in a Globalized Marketplace for Professional Services, 80 N.Y. ST. B. Ass'N J. 39, 39 (2008).

261. HEINZ ET AL., supra note 27, at 301-02; Dzienkowski, supra note 243, at 3001 .

262. Kenneth A. Cutshaw, Ronit Kochhar \& Kochhar \& Co., Corporate Counsel's Guide to Doing Business In India $\S \S 12: 1-: 18$ (3d ed. 2014).

263. CARSON, supra note 42, at 2.

264. Id.

265. Id. Note that all of these figures include only licensed lawyers, not law school graduates. 
The ongoing migration of newly licensed lawyers to non-legal work suggests that this supply has outpaced demand. ${ }^{266}$ The impact of this oversupply, furthermore, will be difficult to mitigate. Recent reductions in law school enrollment will moderate the supply of entry-level lawyers, ${ }^{267}$ but those cutbacks will do little to decrease the overall profession's size unless schools maintain the reductions. ${ }^{268}$ The persistent gap between supply and demand will allow employers to continue disaggregating legal work, hiring lawyers at lower salaries, and pushing those attorneys into contingent and part-time positions.

$$
* \quad * \quad *
$$

Two common threads run through each of these six forces: Each has substantially affected the structure of the legal profession, and each will continue to grow in power. We cannot predict the precise shape of the legal profession in ten years, but it would be foolhardy to ignore these trends. Although the recession ended six years ago, members of the Class of 2010 remain underemployedand more recent classes continue to show distress in their nine-month employment figures. ${ }^{269}$ Law school applications have fallen

\section{See supra Section II.F.}

267. See ABA Section of Legal Education Reports 2014 Law School Enrollment Data, ABA (Dec. 16, 2014, 11:18 AM), http:/www.americanbar.org/ news/abanews/aba-news-archives/2014/12/aba_section_of_legal.html (reporting first-year enrollment decline of $27.7 \%$ between fall 2010 and fall 2014).

268. Law schools reduced first-year enrollment by 14,564 students between 2010 and 2014. Id. That number, however, constitutes only $1.1 \%$ of the current legal profession. See Am. Bar Ass'n, National Lawyer Population by State (2013), http://www.americanbar.org/content/dam/aba/migrated/marketresearch/PublicDocu ments/2013 natl_lawyer_by_state.authcheckdam.pdf (reporting 1,268,011 active lawyers in 2013). For further discussion of oversupply in the legal profession, see BRian Z. TAMANAHA, FAILING LAW SchoOls (2012).

269. Among those who graduated in 2012 or 2013, more than one-tenth were unemployed and seeking work nine months after graduation (a figure that does not include other unemployed graduates who were not actively seeking work). ABA Section of Legal Educ. \& Admissions to the Bar, 2013 Law Graduate EMPLOYMENT DATA (2014) [hereinafter 2013 EMPLOYMENT DATA], http://www. americanbar.org/content/dam/aba/administrative/legal_education_and_admissions to_the_bar/statistics/2013_law_graduate_employment_data.authcheckdam.pdf (reporting results for both 2012 and 2013). Only 56\%-57\% of these classes obtained full-time, ongoing work in jobs that required bar admission. $I d$.

Percentages were slightly better for the Class of 2014, largely because the class size dropped by $6.5 \%$. See ABA SECTION OF Legal Educ. \& AdMissions to the BAR, 2014 LAW GRAduAte Employment Data (2015) [hereinafter 2014 EMPLOYMENT DATA], http://www.americanbar.org/content/dam/aba/administrative/ legal_education_and_admissions_to_the_bar/statistics/2014_law_graduate employment_data_0 $\overline{4} 2915$.authcheckdam.pdf. Nationally, $9.8 \%$ of the Class of 2014 
dramatically, ${ }^{270}$ and some law schools are struggling to fill their classes. ${ }^{271}$ To address all of these needs, it is time to make some hardheaded calculations about the market for entry-level lawyers and the revenue stream for JD programs.

\section{B. Entry-Level Lawyers and the Economics of Legal Education}

The results of the current study, combined with previous research, support two predictions about the market for entry-level lawyers. First, the demand for licensed lawyers will remain flat; it is unlikely to exceed 29,250 lawyers per year. Second, a majority of those jobs will be as solo practitioners, associates in very small (two to ten lawyer) firms, staff attorneys at larger firms, state or local government workers, public defenders, and legal aid attorneys. None of these jobs will offer the high income levels associated with partnership-track positions in larger law firms. ${ }^{272}$

These predictions, in turn, yield two forecasts for legal education. First, students will be less willing to pursue a JD for jobs that are merely law-related; they will invest in three years of legal education primarily when that purchase offers them a strong probability of obtaining work as a licensed lawyer. Second, the market will continue to restrain JD tuition. The preponderance of lower paying jobs, together with increased transparency of career

was unemployed ten months after graduation, while $59.9 \%$ of the class had secured full-time, ongoing work in jobs requiring bar admission. Id.

270. Law school applicants declined from 87,900 in 2010 to 55,700 in 2014, a drop of more than one-third. End-Of-Year Summary: ABA (Applicants, Applications, \& Admissions), LSATS, Credential Assembly Service, LSAC, http://www.lsac.org/lsacresources/data/lsac-volume-summary (last visited Sept. 21, 2015). Final figures are not yet available for fall 2015 but, as of August 8, 2015, the number of applicants had decreased another $1.8 \%$ compared to the same point last year. Three-Year Applicant Volume Graphs, LSAC, http://www.lsac.org/ lsacresources/data/three-year-volume (last visited Sept. 21, 2015).

271. See Catherine Ho, At Region's Law Schools, a Struggle to Get Students, WASH. POST (Sept. 15, 2013), http://www.washingtonpost.com/business/ capitalbusiness/at-regions-law-schools-a-struggle-to-get-students/2013/09/13/ b8e2e6a8-1995-11e3-a628-7e6dde8f889d_story.html.

272. It is possible that some of these positions will generate more income than the jobholders would have earned if they had entered the workplace with just a college degree. See Simkovic \& McIntyre, supra note 5 (calculating the historic income premium conferred by a JD over a BA). The key question for law schools, however, is how many of today's students will pay law school tuition for these outcomes rather than invest in other careers (including other graduate programs). 
outcomes, will reduce students' willingness to pay tuition at the high levels set in 2010-2012. ${ }^{273}$

In offering these forecasts, I try to make their foundations visible so that others can assess them. I also err on the side of protecting educational institutions and their graduates: In the current market, the consequences of over-estimating demand for licensed lawyers seem much greater than those of under-estimation. If schools do not produce enough lawyers, salaries will rise for recent graduates and schools will quickly enroll more students. If schools continue to over-produce lawyers, in contrast, salaries and job conditions may decline further for alumni; employment rates will fall; and at least some schools may find themselves in a downward spiral of worsening placement rates, falling applicant numbers, and declining applicant credentials.

\section{Flat Demand for New Lawyers}

Considerable research suggests that the supply of licensed lawyers has outstripped demand for at least two decades. Heinz and Laumann found that the percentage of Chicago lawyers practicing law slipped between 1975 and 1995; AJD confirmed that the percentage was even lower for junior lawyers during the first decade of this century. ${ }^{274}$ Outcomes for the research population were even worse: four years after bar admission, only three-quarters of the population worked in jobs that required a law license. ${ }^{275}$ Adjusting that figure to account for law graduates who never took or passed the bar exam, just two-thirds of the Class of 2010 (as represented by the research population) currently practice law. ${ }^{276}$

If the research population tracks nationwide outcomes, then about 29,250 graduates from the Class of 2010 are currently practicing law. ${ }^{277}$ On its own, that figure augurs bad news for recent

273. See, e.g., Campos, supra note 6; Merritt, supra note 6, at 21-24.

274. See supra notes 159-63 and accompanying text.

275. See supra text following note 163.

276. See supra note 167 and accompanying text.

277. Forty-four thousand two hundred fifty-eight $(44,258)$ students received a JD from an ABA-accredited law school in 2010. ABA SECTION OF LEGAL EDUC. \& Admissions to THE BAR, JD. AND LL.B Degrees Awarded 1981-2011, http://www.americanbar.org/content/dam/aba/administrative/legal_education_and_a dmissions to the bar/statistics/jd llb_degrees_awarded.authcheckdam.pdf ${ }^{-}$(last visited Sept. $\overline{2} 1, \overline{2015}$ ). About $88.0 \%$ of those graduates nationally were admitted to the bar. See supra note 164. About 38,947 graduates, therefore, joined the bar. Applying the percentage of lawyering jobs from the research population $(75.1 \%)$ to 
law school graduates: A third of them are unable to use their degrees as practicing lawyers. ${ }^{278}$ When combined with figures drawn from the Class of 2000, however, the results are even more troubling.

The Class of 2000 included 38,158 graduates from ABAaccredited law schools. ${ }^{279}$ Using the calculations described above, about 33,579 of them obtained law licenses. ${ }^{280}$ Responses to the $A J D$ survey suggest that $85.3 \%$ of these licensed lawyers were practicing law three years after graduation. ${ }^{281}$ About 28,650 members of the Class of 2000, therefore, found sustainable jobs that required a law license.

This figure is remarkably close to the one calculated for the Class of 2010. If these estimates are correct, then annual demand for newly licensed lawyers increased only marginally (about 2.1\%) between 2003 and 2014. The profession has continued to grow and to absorb new lawyers as part of that growth, but the yearly demand for new lawyers has not increased. At least from the perspective of junior attorneys, structural shifts in the employment market have offset some of the increased demand for legal services.

The figures calculated above also correspond quite well with the number of full-time lawyering positions reported to NALP nine

that number yields a final estimate of 29,249 class members practicing law in December 2014.

278. I recognize that many law school graduates find satisfaction in careers outside of law practice. Simkovic and McIntyre have also shown that for previous generations, a JD conferred substantial financial advantages (compared to a BA) even for graduates who did not practice law. Simkovic \& McIntyre, supra note 5. Surveys, however, repeatedly show that law graduates prefer to practice law. See infra notes 293-96. Undertaking both law school and the bar exam without any intention of practicing law seems like an onerous task.

279. JD. AND LL.B DEGREES AWARDED, supra note 277.

280. The National Conference of Bar Examiners, unfortunately, did not report separate categories of first-time and repeat takers from ABA-accredited law schools during the early years of this century. To derive the figure in text, I used the estimate of $88 \%$ eventual bar admission calculated for the Class of 2010. See supra note 164. It is possible that the percentage should be lower for the Class of 2000, because overall bar passage rates were lower in the late 1990s and early 2000s (after states raised passing scores) than later in the decade. Id. It is impossible, however, to separate the different categories of examinees during the earlier period.

If we lower the percentage of eventual bar admission for the Class of 2000 by another three points, to $85 \%$, then the number of licensed graduates in that class would be 32,434 , and the number practicing law three years after graduation would fall to about 27,666 . That figure would produce a higher increase in demand (about 5.7\%) for newly licensed lawyers between 2000 and 2010, but it assumes dismal bar outcomes for graduates of ABA-accredited law schools in 2000.

281. See supra note 92 and accompanying text. 
months after graduation. For the Class of 2000, that number was 26,764; for the Class of 2010, it was 25,654. ${ }^{282}$ Members of both classes secured more lawyering jobs as they established themselves as lawyers, but the number of practice positions did not expand beyond 29,250.

Going forward, demand for early career lawyers seems unlikely to rise much above that figure. Nine months after graduation, members of the Class of 2012 held 26,066 full-time, long-term jobs requiring bar admission. ${ }^{283}$ For the Class of 2013, the total was 26,653, while for the Class of 2014 it was just 26,248. ${ }^{284}$ As with earlier classes, these numbers will grow modestly as the graduates gain bar admission and workplace experience. The numbers, however, do not seem poised to rise above those attained by the Classes of 2000 or 2010. Nor do other signs suggest a dramatic increase in demand for early career lawyers - certainly not one that would employ substantially more lawyers than those from the Class of 2000 .

Indeed, technology, disaggregation, and other forces may push demand still lower. Even now, billable hours per lawyer remain depressed at law firms. ${ }^{285}$ Many firms have also discarded their upor-out policies, creating a stable of mid-level attorneys who reduce the need for new associates. ${ }^{286}$ The recent past, in other words, predicts demand for about 29,250 newly licensed lawyers per year. ${ }^{287}$ Evolving trends suggest the number could fall even lower.

282. JoBs \& JDs 2000, supra note 88 , at 8 ; JoBs \& JDs 2010, supra note 43, at 8 .

283. 2013 EMPLOYMENT DATA, supra note 269. For the most recent graduates, the ABA distinguishes between "long-term" and "short-term" jobs. The former jobs are expected to last for more than a year, while the latter are expected to end within that period. Id. I focus here on long-term jobs, both because they are most relevant to prospective students and because they are most comparable to jobs provided in earlier periods (before schools and other employers created bridge jobs for recent graduates).

284. 2014 EMPLOYMENT DATA, supra note 269.

285. 2015 REPORT, supra note 246, at 4. As the authors of the report note, most "categories of lawyer timekeepers . . . have consistently remained between 100 and 200 hours per person per year lower than in 2007." Id. The only exception is among associates, where hours remain depressed but the gap is not as large. Id.

286. Burk, supra note 4, at 588; AltMAN WeIL, INC., supra note 236.

287. This number, intriguingly, falls almost halfway between two different forecasts made by the Bureau of Labor Statistics (BLS). Using a traditional method to calculate job turnover, the Bureau projects 199,000 job openings for lawyers and judicial clerks between 2012 and 2022, or about 19,900 positions that require bar admission per year. See Occupational Separations Methodology, BUREAU OF LABOR 


\section{Modest-Paying Legal Jobs}

Based on findings from the research population, practicing lawyers from the Class of 2010 work in very different settings than practitioners from the Class of 2000 did at a comparable point in their careers. The more recent lawyers are almost twice as likely to work as solo practitioners ${ }^{288}$ and less than one-third as likely to work as associates in firms of more than 250 lawyers. ${ }^{289}$ Among population members who were practicing law in December 2014, almost threefifths $(57.0 \%)$ worked as solo practitioners, associates in a small firm of 2-10 lawyers, state or government attorneys, public defenders, legal aid lawyers, or staff attorneys at a large firm. Even when recent graduates obtain lawyering jobs, in other words, those positions increasingly fall in lower-paying segments of the profession.

STAT., http://www.bls.gov/emp/ep_separations.htm (last modified Mar. 5, 2015) (follow "Experimental 2012-22 Data (XLSX)" hyperlink). Using a new, proposed method, the number would be 422,900 , or 42,290 openings per year. Id.

The latter number almost certainly is too high; it far exceeds the number of lawyering jobs detected in $A J D$, this study, and other sources. The flaw in the proposed BLS projection is that it incorporates the high level of exit/entry from the legal profession that has emerged in recent years. As Table X shows, almost onequarter of the research population moved at some point from a lawyering job to one that did not require bar admission. Yet the population as a whole experienced a net increase in lawyering jobs. See supra Table IV. Clearly graduates both exited and reentered the legal profession with some frequency. Under the BLS's proposed method, all of these exits would count as job openings - even though experienced graduates would quickly fill them rather than leaving them as "new openings" for graduates. The former number, based on the evidence now available from $A J D$ and this study, may be too low. On the other hand, the BLS projections forecast how many new entrants will remain in an occupation after a decade has passed, while the current study focuses on outcomes 4.5 years after graduation. AJD shows that a significant number of lawyers leave the profession between the three- and ten-year marks. See supra note 163 and accompanying text. The current study also adopted a generous definition of lawyering work, particularly by counting all graduates who listed themselves as solo practitioners. See supra notes 75-76 and accompanying text.

288. Four years after bar admission, $9.1 \%$ of the research population worked as solo practitioners. See supra Table IV. At a similar point, $5.0 \%$ of the Class of 2000 fell in that category. AJD I, supra note 28, at 27.

289. Three years after graduation, $20 \%$ of the Class of 2000 worked as associates in firms of that size. AJD I, supra note 28 , at 27 . In contrast, just $6.5 \%$ of the research population held associate positions in those firms. The latter figure includes population members working for firms of more than 250 lawyers, see supra Table IV, but excludes individuals working as staff attorneys at those firms. See supra notes 127-28 and accompanying text. 
My data did not include salary information, so it is impossible to quantify this shift. The modest pay for solo practitioners, smallfirm lawyers, and state or local government attorneys, however, is well documented. Twelve years after graduation (in 2012), solo practitioners in the Class of 2000 reported a median income of just $\$ 50,000$, with a full quarter of them reporting no income at all. ${ }^{290}$ Median pay for state and local government lawyers was $\$ 78,000$, with a quarter earning $\$ 59,800$ or less. ${ }^{291}$ Scholars have also found that the income gap between these positions and those at the top of the profession are increasing, with income in the lower-paid portions of the profession stagnating or declining. ${ }^{292}$ This gap commanded relatively little notice while jobs in higher-paid sectors continued to increase. Now that those jobs are shrinking, and junior lawyers are taking more jobs in the lower-paid sector, the disparity will become more prominent.

\section{Law School Enrollment}

As employment for licensed lawyers declined over the last generation, law school graduates took jobs that were law-related but did not require bar admission. Although graduates took these jobs, they have consistently reported less satisfaction with these "JD advantage" jobs than with ones requiring a law license. ${ }^{293}$ Nine months after graduation, for example, almost half of 2010 graduates with JD advantage jobs were seeking other work. ${ }^{294}$ For those with positions requiring bar admission, the percentage was just $15.1 \% .{ }^{295}$ Similarly, $A J D$ respondents who were not using their law licenses

290. Dinovitzer \& Wilkins, supra note 15, at 45; see also Richard Sander, Hidden Transformation of the Legal Industry, ABA Young LAWYERS Div. (June 2008), http://www.americanbar.org/publications/young_lawyer_home/young lawyer_archive/yld_tyl_june 08 sander.html (reporting that average income of solo practitioners was less than $\$ 46,000$ in 2004).

291. Dinovitzer \& Wilkins, supra note 15, at 45.

292. See, e.g., HeINZ ET AL., supra note 27, at 160-61; Barton, supra note 227 , at 30 .

293. The ABA and the NALP began using the phrase "JD advantage" in 2011 as a way to describe "jobs for which bar passage is not required but for which a JD degree provides a distinct advantage." Detailed Analysis of JD Advantage Jobs, NALP (May 2013), http://www.nalp.org/jd_advantage_jobs_detail_may2013.

294. See, e.g., JOBS \& JDs 2010 , supra note 43 , at 102 (reporting $48.1 \%$ for graduates doing "JD preferred" work, the phrase previously used to describe "JD advantage" jobs).

295. Id. 
expressed lower satisfaction levels than colleagues who were practicing. ${ }^{296}$

Even a law school dean has acknowledged that "a JD makes no sense" for jobs in compliance, human resources, criminal justice, law firm management, and other law-related positions. ${ }^{297}$ The most rational use of a law degree, at least during the early years of a career, is to practice law. ${ }^{298}$ If students want an intellectually challenging graduate program that prepares them for diverse careers, including ones that are law-related, today's universities offer many options: master's degrees in business, public affairs, public health, computer science, environmental engineering, and data analytics are just some of the opportunities. ${ }^{299}$ Even an undergraduate degree in

296. AJD II, supra note 62, at 70 (reporting that seven years after graduation, only $64.3 \%$ of graduates working in business non-lawyering jobs were "extremely to moderately satisfied" with their decision to become a lawyer; for other groups, those levels ranged from $68.9 \%$ to $82.5 \%$ ); Sterling, Sandefur \& Plickert, supra note 178 , at 70 (reporting similar results for lawyers twelve years after graduation).

297. Martha Neil, Schools Market to Mid-Career Professionals as Fewer Traditional Students Seek Law Degrees, ABA Journal (May 20, 2013, 2:00 PM), http://www.abajournal.com/news/article/as_fewer_traditional_students_seek_law_ degrees_schools_market_to_mid-career/ (quoting Frank Wu, Chancellor of the Hastings College of Law). Wu made this comment to encourage enrollment in master's programs that schools have created for professionals in law-related fields. Id. The remark demonstrates the tension between those programs and schools' continued endorsement of non-practice positions for their JD graduates.

298. See Burk, supra note 4, at 543-44 (stating that law school is a "rational substantive preparation" only for jobs that "require the degree as a condition of employment, or" for which "the course of study provides dramatic and substantial advantages (as opposed to being merely relevant or useful) in obtaining or performing the job that are not more easily obtainable or substitutable (whether in nature or extent) another way").

299. Student demand for MBA degrees has exploded in recent years: Universities awarded 188,600 of those degrees in 2012-2013, which is $47.7 \%$ more than the number $(127,700)$ awarded a decade earlier. Graduate Degree Fields, NAT'L CTR. FOR EDUC. STAT., http://nces.ed.gov/programs/coe/indicator_ctb.asp (last updated Apr. 2015). BBC News recently reported on the strong demand for these graduates. Andrew Eder, Newly Minted MBA? It's the Best Job Market in Years, BBC CAPITAL (Mar. 2, 2015), http://www.bbc.com/capital/story/20150227bull-market-for-us-business-grads. Degrees in public health, public affairs, computer science, and environmental engineering all match growth areas of the economy-as well as the interests of contemporary students. Data analytics is a recent, rapidly growing field with employer demand in a large number of industries. See generally MASTER's IN DATA SCI., http://www.mastersindatascience.org/ (last visited Sept. 21, 2015). 
one of these disciplines can adequately prepare a student for work in compliance, criminal justice, and other law-related fields. ${ }^{300}$

The expansion of these other fields, combined with increased transparency about JD career outcomes, means that future students are likely to enroll in law school primarily if they want to practice law and their prospective law school places a reasonable percentage of graduates in practice positions. ${ }^{301}$ No one knows exactly what outcomes will attract these students, but I predict that they will want to see about $85 \%$ of a school's graduates practicing law several years after graduation. ${ }^{302}$ Otherwise, thoughtful students are likely to pursue other programs that offer equal or better levels of intellectual satisfaction, career flexibility, and employment.

For schools to place $85 \%$ of their graduates in jobs requiring bar admission, how many students will they be able to enroll? The answer depends upon market demand for new lawyers, attrition among JD students, and bar passage rates. If the market will absorb 29,250 new lawyers per year, and if attrition remains at recent levels of $8.7 \%,{ }^{303}$ then law schools could enroll about 37,691 new JD students each year. ${ }^{304}$ That number, notably, falls just slightly below the 37,924 students who enrolled in the fall of 2014. ${ }^{305}$ Current enrollment is close to the level that may produce job outcomes sufficient to attract the most talented students back to law school.

300. See Compliance Managers, Education, supra note 149 (66\% of compliance managers hold a bachelor's degree); Summary Report for: 21-1092.00 Probation Officers and Correctional Treatment Specialists, Education, O*NET ONLINE, http://www.onetonline.org/link/summary/21-1092.00\#Education (last visited Sept. 21,2015$)(86 \%$ of probation officers and other correctional treatment specialists hold a bachelor's degree).

301. Other scholars have made similar predictions about cautiousness in the next generation of law students. See, e.g., Barton, supra note 227, at 31; Burk, supra note 4 .

302. Note that I focus on employment rates three or four years after graduation, like the ones measured in $A J D$ and this study. The percentage of graduates practicing law nine to ten months after graduation will be significantly lower because about one-fifth of graduates from ABA-accredited law schools fail the bar exam on the first try. See 2013 STATISTICS, supra note 164, at 19 (reporting $81 \%$ pass rate for that group in 2013). For this, among other reasons, law schools and the ABA should supplement employment reports with ones assessed at least two years after graduation.

303. I calculated this percentage from the 2014 figures reported by the ABA on its new website. ABA Required Disclosures, supra note 205.

304. After attrition, that number of first-year enrollees would generate 34,412 graduates; 29,250 lawyering jobs would then absorb $85 \%$ of those graduates.

305. ABA Section of Legal Education Reports 2014 Law School Enrollment Data, supra note 267. 
That projection, however, may be optimistic. It assumes, first, that that the market will continue to absorb 29,250 recently licensed attorneys each year in jobs that both require bar admission and persist for several years after graduation. That assumption, in turn, depends upon the premise that increased demand for legal services will continue to offset the forces described above. If demand falters, or those forces increase in strength, jobs for newly licensed attorneys could contract even further.

Equally important, my estimate assumes that bar passage rates remain relatively steady. If the recent decline in law school credentials produces a corresponding decrease in bar passage rates, ${ }^{306}$ then schools will have to shrink class size simply to maintain bar passage rates and palatable employment levels in jobs that require bar admission. Under these circumstances, the projected class size of 37,691 first-year students would serve as an upper limit on sustainable class sizes.

The market and student tastes, of course, could also move in the other direction. Market shifts could increase demand for licensed lawyers; students, alternatively, could develop a greater willingness to apply legal education to JD-advantage work. The likelihood of those changes, however, seems small given the number of forces pressing in the other direction. For the foreseeable future, three common factors are likely to constrain JD enrollment: (a) prospective students will seek high placement rates in jobs that require bar admission; (b) the number of those jobs available to entry-level lawyers will be stable at best; and (c) a pool of less qualified applicants may threaten bar-passage rates as well as job placement for positions requiring bar admission. As a result, JD enrollment may not rise much from its current level, even if more qualified applicants return to law school.

\section{JD Tuition}

JD tuition seems to have moderated or fallen over the last three years. Although most law schools have raised list prices, evidence suggests that they are discounting those prices more heavily-and

306. Professor Jerry Organ offers detailed data about declining credentials (primarily as measured by LSAT) and predicts a fall in bar passage rates. Jerry Organ, The Composition of Graduating Classes of Law Students-2013-2016-Part One, The Legal WhiteBOARD (Dec. 29, 2014), http://lawprofessors.typepad.com/ legalwhiteboard/2014/12/the-composition-of-graduating-classes-of-law-students2013-2016-part-one-.html. 
for more students. ${ }^{307}$ Yet applications continue to drop, indicating that tuition has not yet reached the market level. ${ }^{308}$

The results of the current study confirm that indication; indeed, the employment conditions reported here suggest that tuition may fall even lower. Among the practicing lawyers in the research population, almost three-fifths $(57 \%)$ worked in jobs with historically modest salaries. Students contemplating those income levels seem unlikely to pay 2010 tuition levels for their legal education. If they do, they will remain deeply in debt through middle age, and Congress may decide that it can no longer afford to underwrite these loans.

To understand this forecast, it is useful to look back once more at the Class of 2000. Three years after graduation, $84.0 \%$ of that class carried educational loans; median debt (after three years of repayment) was $\$ 70,000$; and $20.3 \%$ of the class owed more than $\$ 100,000 .{ }^{309}$ Four years later, the percentage with debt had fallen to $63.8 \%$; median debt in that group was about $\$ 50,000$; and $8.2 \%$ of the class owed more than $\$ 100,000 .{ }^{310}$ These figures suggest steady progress in loan repayment, but they hardly suggest rapid, easy payment. These repayments, furthermore, occurred with strong employment outcomes during a prosperous era. ${ }^{311}$

By the 2012-2013 academic year, students were borrowing an average of $\$ 32,289$ each year to attend a public law school and $\$ 44,094$ for a private one. ${ }^{312}$ The prospect of paying off $\$ 97,000$ to $\$ 132,000$ of law school debt, plus college debt, plus accrued interest-all with weaker employment outcomes than earlier

307. See, e.g., Brian Z. Tamanaha, The Collapsing Economics of Legal Education, 14 Engage: J. Federalist Soc'y PraC. Groups 61, 61 (2013); Carol Ann Alaimo, UA Law School to Undercut Peers with Deep Tuition Discounts, ARIz. DAILY STAR (May 26, 2014, 12:00 AM), http:/tucson.com/news/local/education/ college/ua-law-school-to-undercut-peers-with-deep-tuition-discounts/article 670765a2-b51b-51cd-9cfb-642f410aecf5.html; Chelsea Phipps, More Law Schools Haggle on Scholarships, WALL ST. JouRnAL (July 29, 2012, 9:23 PM), http://www.wsj.com/articles/SB10000872396390444130304577557182667927226.

308. See supra note 270.

309. Rebecca Sandefur, Bryant G. Garth \& Joyce Sterling, Financing Legal Education-The View Twelve Years Out of Law School, in AJD III, supra note 9, at $79,81$.

310. Id.

311. See supra notes 91-95 and accompanying text.

312. Statistics, ABA, http://www.americanbar.org/groups/legal_education/ resources/statistics.html (last visited Sept. 21, 2015) (follow "Average Amount Borrowed" hyperlink under "Financial Information"). These figures are the most recent ones released by the $\mathrm{ABA}$. 
classes - may overwhelm prospective students. ${ }^{313}$ Federal taxpayers are already expressing concern about programs that excuse substantial amounts of this debt, ${ }^{314}$ and the next generation of students shows more concern about educational loans than recent cohorts. ${ }^{315}$ To continue attracting talented students to JD programs, most law schools will have to continue moderating law school tuition.

\section{CONCLUSION}

The results of this study offer discouraging forecasts for both newly licensed lawyers and traditional JD programs. Even after several years in the workforce, members of the Class of 2010 struggle to secure jobs that require bar admission. Law firm jobs are scarcer than in the past, and other employers have not made up the shortfall. Most positions fall within modest paying categories: solo practice, small firms, government work, and business jobs that do not require bar admission. These outcomes are challenging for students who borrowed heavily to finance their degrees; they are also discouraging for graduates who hoped to work as practicing lawyers but were not able to secure those positions.

313. AJD respondents who still owed more than $\$ 100,000$ in educational debt seven years after receiving their JDs were significantly less satisfied than other respondents with their law school investment. Ronit Dinovitzer, Bryant G. Garth \& Joyce S. Sterling, Buyers' Remorse? An Empirical Assessment of the Desirability of a Lawyer Career, 63 J. Legal Educ. 211, 221 (2013). That finding bodes ill for more recent law school graduates, a much larger percentage of whom will carry that amount of debt throughout their early careers. See generally TAMANAHA, supra note 268, at 154-59 (discussing impact of law school debt on graduates).

314. See, e.g., Jason Delisle, Obama Budget Reforms Income-Based Repayment, Reduces Windfall Benefits, New AM. EdCENTRAL (Mar. 4, 2014), http://www.edcentral.org/obama-administration-announces-major-reforms-incomebased-repayment/.

315. See, e.g., Emily DeRuy, Millennials' Biggest Financial Concern Is Student Loan Debt, Fusion (June 12, 2014, 2:18 PM), http://fusion.net/story/5932/millennials-biggest-financial-concern-is-student-loandebt/ (survey by Wells Fargo shows that educational debt is millennials' biggest financial concern; three-fifths are concerned about the value they received for tuition); 'Generation Z' Is Entrepreneurial, Wants to Chart Its Own Future, NORTHEASTERn News (Nov. 18, 2014), http://www.northeastern.edu/news/2014/ 11/generation-z-survey/ (reporting national survey results revealing that high school students are very reluctant to assume educational debt; $25 \%$ don't want to incur any debt); see also Barton, supra note 227, at 31 (noting that future law students will seek to "reduce borrowing, freeing them to take jobs they like rather than jobs that repay loans"). 
For law schools, the results offer strong evidence of structural changes that will keep JD enrollment and tuition depressed. To place a significant percentage of graduates in jobs that require a law degree, enrollment will have to remain close to 2014 levels. To continue attracting sufficiently talented students, effective tuition rates will also stabilize or decline further. Revenue from JD programs will be much lower than schools anticipated a decade ago.

There is, however, an attractive path forward for law schools and future students. The contraction of JD enrollment, combined with the expansion of law-related jobs, offers an ideal time to restructure legal education. If law schools moved the first year of legal study into the undergraduate curriculum, creating a liberal arts major in law, they could educate a large number of students in both the core principles of our legal system and the critical skill of "thinking like a lawyer." The students, their future employers, and civil society would all benefit. At the same time, schools could retain the upper-level curriculum as a two-year JD program. ${ }^{316}$

This division would allow law schools to maintain their role as teachers of critical thinking, while also consolidating the JD curriculum into an advanced program focused on preparing graduates for contemporary law practice. For students, the new structure would offer a richer educational sequence at reduced costs. ${ }^{317}$ Clients and society, finally, would obtain a better mix of

316. Several other educators have proposed moving portions of legal education to the undergraduate curriculum, although details differ. See, e.g., Campos, supra note 6, at 220-21; Douglas A. Kahn, Time for Radical Change in Legal Education: Students Would Save Three Years of Tuition if They Could Enter Law School After Their Freshman Year, 35 NAT'L L.J. 42 (2013); John O. McGinnis \& Russell D. Mangas, An Undergraduate Option for Legal Education, 38 INT'L REv. L. \& ECON. 117 (2014); Ben Barros, Moving Part of Legal Education to the Undergraduate Level - Advanced Placement for Law Schools, THE FACULTY LOUNGE (Feb. 27, 2013, 12:22 PM), http://www.thefacultylounge.org/2013/02/ moving-part-of-legal-education-to-the-undergraduate-level-advanced-placement-forlaw-schools.html. The University of Arizona's James E. Rogers College of Law, collaborating with the University's School of Government and Public Policy, recently established a Bachelor of Arts in Law. See Bachelor of Arts: Law, UNIV. OF ARIZ. SCH. OF GOV'T \& PUB. POLICY, http://sgpp.arizona.edu/bachelor-arts-law (last visited Sept. 21, 2015). That major does not currently substitute for any portion of law school; changes in bar admission and law school accreditation standards would be necessary to achieve that goal.

317. College students would be able to obtain the skills and knowledge currently taught during the first year of law school as part of the price of attending college. They would also be able to study law along with other subjects, more readily making the interdisciplinary connections that the first year attempts to foster. This major, combined with summer jobs or externships, would also help students 
licensed lawyers and law-knowledgeable graduates. The details of that proposal lie beyond the scope of this Article, ${ }^{318}$ but the employment patterns documented here confirm the need for creative adaptation in legal education.

make a more informed choice about whether to become licensed attorneys. Some might postpone that decision until after gaining experience in a law-related job.

Students who decided to become licensed attorneys, meanwhile, would complete their education in six years rather than seven. They would also pay just two years of law school tuition. Perhaps most important, their smaller JD classes would support more hands-on problem solving and clinical work.

318. For some initial thoughts, see Deborah J. Merritt, Four Plus Two, LAW SCH. CAFE (Nov. 17, 2013, 9:12 PM), http://www.lawschoolcafe.org/thread/fourplus-two/; Deborah J. Merritt, Committing to Law, LAw SCH. CAFE (Nov. 19, 2013, 1:23 PM), http://www.lawschoolcafe.org/thread/committing-to-law/; Deborah J. Merritt, What About the Bar Exam?, LAw School CAFE (Nov. 25, 2013, 7:59 PM), http://www.lawschoolcafe.org/thread/what-about-the-bar-exam/. 
